\title{
Non-Invasive On-Site Raman Study of Pigments and Glassy Matrix of 17th-18th Century Painted Enamelled Chinese Metal Wares: Comparison with French Enamelling Technology
}

\author{
Philippe Colomban 1,*(D), Burcu Kırmız 1,2 ${ }^{1}$, Bing Zhao ${ }^{3}$, Jean-Baptiste Clais ${ }^{4}$, Yong Yang 5 \\ and Vincent Droguet ${ }^{6}$ \\ 1 MONARIS UMR8233, Sorbonne Université, CNRS, 4 Place Jussieu, 75005 Paris, France; \\ burcu.kirmizi@yahoo.com \\ 2 Department of Conservation and Restoration of Cultural Property, Faculty of Architecture, Ylldiz Technical \\ University, Yıldız Yerleşkesi B Blok, Beşiktaş, 34349 İstanbul, Turkey \\ 3 CRCAO UMR8155, Collège de France, CNRS, 75005 Paris, France; bing.zhao@college-de-france.fr \\ 4 Département des objets d'art, Musée du Louvre, quai François Mitterand, 75001 Paris, France; \\ jean-baptiste.clais@louvre.fr \\ 5 Department of Fine Arts, Palace Museum, Beijing 100009, China; yangyong@dpm.org.cn \\ 6 Chateau-Musée de Fontainebleau, Place Charles de Gaulle, 77300 Fontainebleau, France; \\ Vincent.droguet@culture.gouv.fr \\ * Correspondence: philippe.colomban@sorbonne-universite.fr or philippe.colomban@upmc.fr
}

Received: 23 April 2020; Accepted: 7 May 2020; Published: 12 May 2020

\begin{abstract}
A selection of 10 Chinese enamelled metal wares dating from the 17th-18th centuries (Qing Dynasty) was analysed on-site by mobile Raman microspectroscopy. These wares display cloisonné and/or painted enamels and belong to the collections of Musée du Louvre in Paris and Musée Chinois at the Fontainebleau Castle in France. Pigments (Naples yellow lead pyrochlore, hematite, manganese oxide etc.), opacifiers (fluorite, lead arsenates) and corresponding lead-based glassy matrices were identified. One artefact was also analysed by portable X-ray fluorescence spectrometry (pXRF) in order to confirm the Raman data. In some of these metal wares, it is suggested that cassiterite was unpredictably used as an opacifier in some parts of the decor. The results are compared to previous data obtained on Chinese cloisonné and Limoges enamels as well as recent data recorded on painted enamelled porcelains of the Qing Dynasty. Lead arsenate apatite detected in some of the 17th-18th century blue enamelled decors is related to the use of arsenic-rich European cobalt ores, as also characterized in French soft-paste porcelain and glass decors and high-quality Limoges enamels for the same period. However, lead arsenate could then also have been deliberately used for white opacification. The specific Raman signature displaying the shape of the Raman scattering background indicates the presence of colloidal gold ( $\mathrm{Au}^{\circ}$ nanoparticles) in red to violet enamelled and cloisonné areas. At least three types of Naples yellow lead pyrochlore pigments identified with Sb-rich, Sn-rich and mixed $\mathrm{Sb}-\mathrm{Sn}-(\mathrm{Zn}, \mathrm{Fe}$ ?) compositions prove the use of European pigments/recipes.
\end{abstract}

Keywords: Chinese enamels; raman microspectroscopy; fine art; pigments; cobalt; arsenic; gold; Naples Yellow pyrochlore; cassiterite

\section{Introduction}

An enamel can be defined as a glassy material, made by mixing various types of fluxes and colouring/opacifying agents with silica, which is discretely applied and fused onto several bases upon subsequent firing in order to get a glossy coating [1,2]. Enamelled objects, either with ceramic, glass or 
metal bases, have been produced for millennia [3-7]. The origins of all enamelling processes can be traced back to the second millennium B.C.E., particularly in China, Mesopotamia and Egypt, with the production of glazed pottery [4,5]. Complex enamelled glasses were also first encountered in Egypt, dating to the 15th century B.C.E. [6] whereas the earliest examples of enamelled metal were found in Cyprus, Mycenaean Greece and China at about the same time period [3,7,8]. In terms of enamels on metal, the enamelling procedure requires a high level of expertise and skills both involving the technical know-how of glass-making and metalworking as well as the ability to overcome the technical difficulties of joining the different substrates. Thus, the earliest enamel applications were carried out onto gold and silver [8], such as in the golden cloisonné rings of Bronze Age Cyprus [7]. Copper and copper alloys (bronze and brass) were also commonly used due to their easier accessibility [3]. Several'cultures including the Celts and Romans adopted the craft of enamelling on metal for producing more sophisticated decorations and correspondingly developed various techniques such as champlevé (the support is curved in order to make valleys in which the molten glass is retained) and cloisonné (pieces of metal foil set perpendicularly to the substrate are stuck in order to form walls that retain the molten glass according to the target design) $[3,9,10]$. The cloisonné technique was perfected by Celtic and then Byzantine craftsmen mainly from the 8th century onwards [9-11]. The technique then reached China from the West, most probably in relation to trade activities via the Silk Road [3,12,13]. Chinese cloisonné masterpieces started to be widely produced at the time of the Ming Dynasty (1368-1644) [12-15].

Both Chinese and European historical records report that French Ambassador of Louis XIV, the Sun King and the Jesuit missionaries, who were mainly from France but also from Germany and Italy and hosted at the Kangxi Court during the 17th century [16-23], gave outstanding enamelled artefacts as presents to the Emperor and forthcoming Mandarins. Among these presents were enamelled watches [24], Limoges enamelled objects [25,26], etc. which offer a complex realistic painted decor of enamels reproducing famous contemporary oil paintings and fashionable decors, such as in painted enamel miniatures on metal objects. Historical records also mention that on the express demand of Kangxi Emperor (in 1696), this advanced enamelling technology was taught to Chinese craftsmen of the court in workshops established inside the Beijing Forbidden Palace [17]. Archives of the Qing Palace mention that pigments and ingredients required to make such enamels were imported from Europe and this trade was regularly followed [17-21]. Indeed, long before that period, this technique had been first perfected in Limoges during the 15th-16th centuries with the serial production of various types of enamelled copper-alloy objects with polychrome decorations covering the metal surface, with an advanced technical knowledge of using different enamel compositions and firing cycles $[12,13,24-26]$ and then in Blois and Paris during the 17th century for the production of painted enamelled watches, clocks and snuffboxes [24]. At that time, the decor of Chinese porcelains was only made with the blue underglaze decor or with 'couleurs transparentes' technique (wucai, use of transition metal ions dissolved in the silicate network of the glaze) $[1,2,27,28]$ which led to decors rather similar to those obtained on paper with lavish or watercolour techniques. These productions did not permit representing a 'realistic' decor, as opposed to the well-delimited coloured areas filled with opaque enamels that were coloured with pigments and metal nanoparticles (called fencai or yangcai which mean foreign colours, or Famille rose regarding the porcelain for Western scholars), using techniques developed in Europe to decorate metal, glass and pottery which allowed for realizing miniature pictures of enamel [2,12,13,29,30], as in European easel oil paintings, tempera or pastels [31,32]. There is a series of Chinese terms to classify enamelled porcelains: doucai (meaning: bound colours), (su)sancai (three colours), wucai (five colours, also called Famille verte in Western literature), ruancai (soft colours), falangcai (enamels in the French style), fencai (powdered colours), yangcai (Western colours/Famille rose). There are also many terms for monochrome colours (e.g., yanghong western red, etc.). Actually, contours of classification are blurred, overlapped and subjective.

The cloisonné technique actually offers the possibility to have opaque colours but making walls with thin metal foils limits the resolution and colour palette. Indeed, the main advantage of painted enamelled decor made with opaque colours is the possibility to mix them and hence to have a quasi- 
infinite palette of colours (e.g., huafalang porcelains). Although some analytical studies have been published about Chinese metal wares $[12,13,33,34]$, no combined analytical/spectroscopical study has been conducted on outstanding painted enamelled artefacts from the Qing Dynasty.

In this study, we present the first non-invasive on-site study of 10 enamelled metal wares dating to the 17th-18th centuries (Qing Dynasty) from the collections of Musée du Louvre (Département des Objets d'art, Paris) and Chateau de Fontainebleau (Musée Chinois, Fontainebleau) by mobile Raman microspectroscopy. These metal wares were produced by cloisonné and/or painted enamel techniques. Assignments are confirmed with a portable X-ray fluorescence spectrometry instrument (pXRF) study of a representative painted enamelled bottle exhibiting a large palette of colours. However, the high value of the artefacts imposes their preservation in a secure room and any sampling is unquestionably prohibited. Both analysis techniques have the advantage of being handled at the museum and performed without any kind of sample preparation of the artefacts. However, in the case of outstanding artefacts, measurements should be conducted during the closure days of the museum. The condition of recording X-ray fluorescence spectra with a portable instrument and the variable thickness and heterogeneity of the (coloured) coating make the elemental data not be quantitative since light elements are not or poorly detected and the in-depth probed is not the same for each element (see further). The sensitivity of Raman technique is very variable as a function of the nature of the chemical bonds in the probed area/volume and hence some phases could not be detected [24].

Most of the artefacts entered in the French collections during the 19th and early 20th centuries. The collection of Emperor Napoléon III and Empress Eugénie arrived before 1870 and the collection of Adolphe Thiers, former President of the French Republic, arrived in Musée du Louvre in 1922. The study of painted enamelled porcelains from the Qing Dynasty is also presented in a companion paper [35], but two very characteristic examples of painted enamelled porcelains are also included in this study for comparison. The objective of this study is the comparison of the enamelling technology used in these artefacts, regarding cloisonné and painted enamels, with the identification of pigments/opacifiers and glass types used. Outcomes will also be compared with the enamelling technology of cloisonne artefacts produced during the Ming Dynasty (1368-1644) and earlier periods. The study is expected to provide arguments to identify the use of imported enamels or imported enamel recipes from Europe to China at the end of the 17th century under the guidance of Jesuits as reported in the historical records [17-21], in a similar way as that occurred from Europe to Japan during the first part of the 17th century [36-38].

\section{Materials and Methods}

Objects: Table 1 lists the 10 studied metal wares with cloisonné and/or painted enamels and two enamelled porcelains which are shown in Figures 1-4. The studied corpus includes three cloisonné enamelled artefacts, one of which is assigned to the Kangxi reign (1662-1722). The other two artefacts belong to the Qianlong reign (1736-1795). The biggest vase with the Qianlong official mark (Figure 1b) and a pair of outstanding ewers with the Qianlong mark and a very complex decor associating cloisonné and small and large painted medallions are dated to the second half of the 18th century (Figure 2). Seven painted enamelled artefacts including two small dishes, two bottles, an incense tripod and a tea pot are also assigned to the Qianlong reign.

Cloisonné enamelled artefacts have blue, turquoise, yellow, green, red and white areas. Bubbles are observed in the enamel in some cases (see Figure 1a" ${ }^{\prime \prime}$, F1448C; Figure 2e, F1467.1) although rather well-fired enamels, free of visible defects are also present (Figure 1 $b^{\prime}$, F1735C). Painted enamelled areas show a high number of halftones and the quality of the decor can be compared with those obtained by common paintings (see Figure 2c,d,g, F1467.1; Figure 4, see details of R975 and F1698C). The poor gloss and high number of bubbles observed for some of the cloisonné enamels arise from the preparation procedure. The enamelled areas preserved by walls having large but variable thickness normally need to be polished after firing to adjust the enamel thickness of the different coloured areas. This eliminates the upper surface formed at the liquid state, which has a high natural gloss. 
Table 1. The artefacts with painted and/or cloisonné enamels (H: height; D: diameter).

\begin{tabular}{|c|c|c|c|c|c|c|}
\hline Artefacts & $\begin{array}{l}\text { Inventory } \\
\text { Number }\end{array}$ & $\begin{array}{l}\text { Collection/ } \\
\text { Provenance }\end{array}$ & $\begin{array}{l}\text { Place of } \\
\text { Production } \\
\text { (Expected) }\end{array}$ & Period & $\begin{array}{l}\text { Size } \\
(\mathrm{cm})\end{array}$ & Images \\
\hline $\begin{array}{l}\text { Incense tripod, } \\
\text { cloisonné enamel }\end{array}$ & F1448C & & $?$ & $\begin{array}{c}\text { Kangxi period } \\
(1662-1722)\end{array}$ & $\begin{array}{l}\mathrm{H}: 27 \\
\mathrm{D}: 26\end{array}$ & \\
\hline $\begin{array}{l}\text { High vase, } \\
\text { cloisonné enamel }\end{array}$ & F1735C & & & $\begin{array}{c}\text { Qianlong mark } \\
\text { period (1736-1795) }\end{array}$ & $\begin{array}{l}\text { H:103 } \\
\text { D:40 }\end{array}$ & \\
\hline $\begin{array}{l}\text { Bottle, cloisonné } \\
\text { enamel }\end{array}$ & F1501 & & & $\begin{array}{l}\text { Mark?3rd quarter } \\
\text { of } 18 \text { th century }\end{array}$ & $\begin{array}{l}\text { H: } 21 \\
\text { D: } 15\end{array}$ & \\
\hline $\begin{array}{l}\text { Ewer, painted } \\
\text { and cloisonné } \\
\text { enamel on gold } \\
\text { body }\end{array}$ & F1467.1 & & & $\begin{array}{c}\text { 3rd quarter of 18th } \\
\text { century Qianlong } \\
\text { mark }\end{array}$ & & \\
\hline $\begin{array}{l}\text { Ewer, with } \\
\text { painted and } \\
\text { cloisonné enamel } \\
\text { on gold body }\end{array}$ & F1467.2 & & & $\begin{array}{c}\text { 3rd quarter of } 18 \text { th } \\
\text { century Qianlong } \\
\text { mark }\end{array}$ & & \\
\hline $\begin{array}{l}\text { Vase, painted } \\
\text { enamel on } \\
\text { porcelain }\end{array}$ & $F 1341 C$ & & $\begin{array}{l}\text { Jingdezhen } \\
\text { Imperial Factory } \\
\text { of Porcelain }\end{array}$ & $\begin{array}{l}\text { mid-2nd half of } 18 \text { th } \\
\text { century } \\
\text { End of Yongzheng } \\
\text { period }\end{array}$ & $\begin{array}{l}H: 30 \\
D: 15\end{array}$ & \\
\hline $\begin{array}{l}\text { Dish, painted } \\
\text { enamel on } \\
\text { copper body }\end{array}$ & R957 & & Guangzhou & $\begin{array}{l}\text { (1723-1735)_early } \\
\text { Qianlong period: } \\
\text { mid-18th century }\end{array}$ & $\begin{array}{c}\text { H: } 3 \\
\text { D: } 15.5\end{array}$ & \\
\hline $\begin{array}{l}\text { Dish, painted } \\
\text { enamel on } \\
\text { copper body }\end{array}$ & R958 & $\begin{array}{c}\text { Louvre } \\
\text { (Département des } \\
\text { Objets d'Art) }\end{array}$ & Guangzhou & $\begin{array}{l}\text { Qianlong period: } \\
2 \text { nd half of } 18 \text { th } \\
\text { century }\end{array}$ & $\begin{array}{l}\text { H: } 2 \\
\text { D: } 19\end{array}$ & \\
\hline $\begin{array}{l}\text { Bottle, painted } \\
\text { enamel on } \\
\text { copper body } \\
\text { (pXRF studied) }\end{array}$ & R975 & & Guangzhou & $\begin{array}{l}\text { Qianlong period: } \\
\text { 2nd half of 18th } \\
\text { century }\end{array}$ & $\begin{array}{l}\text { H: } 26.5 \\
\text { D: } 14\end{array}$ & \\
\hline $\begin{array}{l}\text { Incense tripod, } \\
\text { painted enamel } \\
\text { on copper body }\end{array}$ & F1698C & & Guangzhou & & $\begin{array}{l}\text { H: } 12.5 \\
\text { D: } 14\end{array}$ & \\
\hline $\begin{array}{l}\text { Bottle, painted } \\
\text { enamel }\end{array}$ & F1440C & $\begin{array}{l}\text { Fontainebleau } \\
\text { (Musée chinois) }\end{array}$ & - & $\begin{array}{l}\text { Qianlong period } \\
\text { (1736-1795): 2nd } \\
\text { half of 18th } \\
\text { century }\end{array}$ & $\begin{array}{c}\text { H: } 21.5 \\
\text { D: } 10\end{array}$ & \\
\hline $\begin{array}{l}\text { Tea pot, of so- } \\
\text { called 'Thousand } \\
\text { flowers Pattern' }\end{array}$ & F1429C & & $\begin{array}{l}\text { Jingdezhen } \\
\text { Imperial Factory } \\
\text { of Porcelain }\end{array}$ & & $\begin{array}{l}H: 13 \\
D: 12 \\
A: 19\end{array}$ & \\
\hline
\end{tabular}




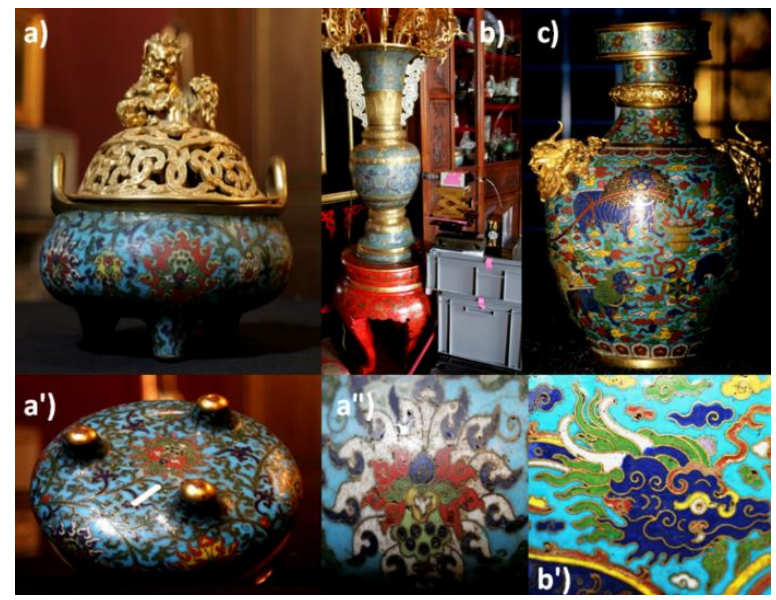

Figure 1. Chinese cloisonné enamelled metal wares from Musée Chinois, Chateau de Fontainebleau: (a) F1448C (17th century, Kangxi Reign, details in a' and a"); (b) F1735C (18th century, Qianlong mark) and (c) F1501 (18th century). See Table 1 for historical information. Note in (b) the optical remote head connected by optic fibres to the laser source and the spectrometer.

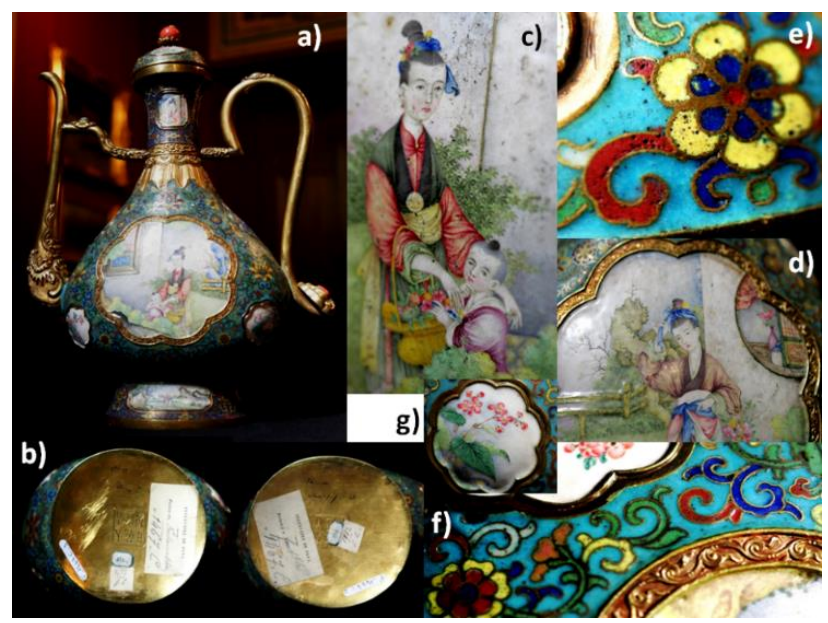

Figure 2. Chinese enamelled ewers with cloisonné and painted decor (F1467.1 and F1467.2): (a) whole view, (b) Qianlong marks on the back face; $(\mathbf{c}, \mathbf{d}, \mathbf{g})$ details of painted decor; $(\mathbf{e}, \mathbf{f})$ details of cloisonné décor.

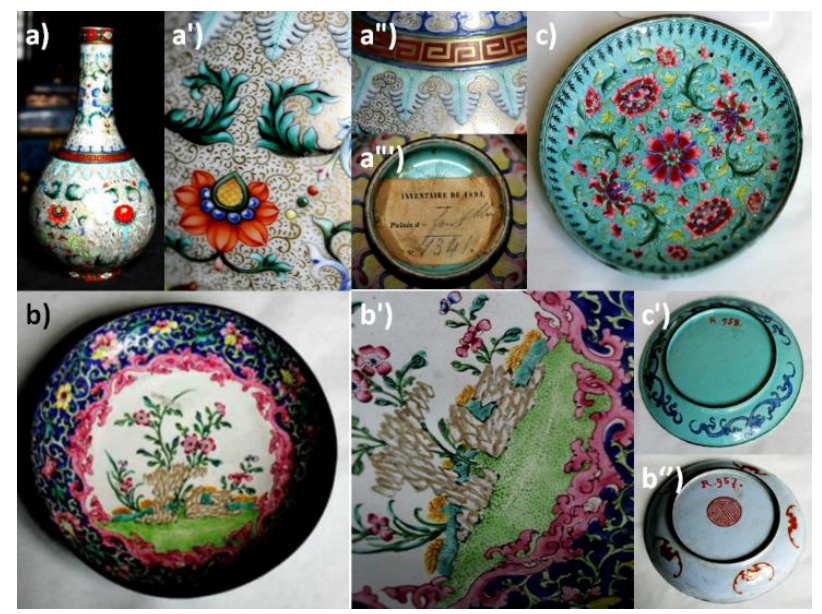

Figure 3. Chinese painted enamelled porcelain and metal wares: (a) F1341C (18th century porcelain, $a^{\prime}$ to $\mathrm{a}^{\prime \prime \prime}$ details); (b) R957 (18th century, b' detail of the decor and b" reverse side); (c) R958 (18th century, $c^{\prime}$ reverse side). 


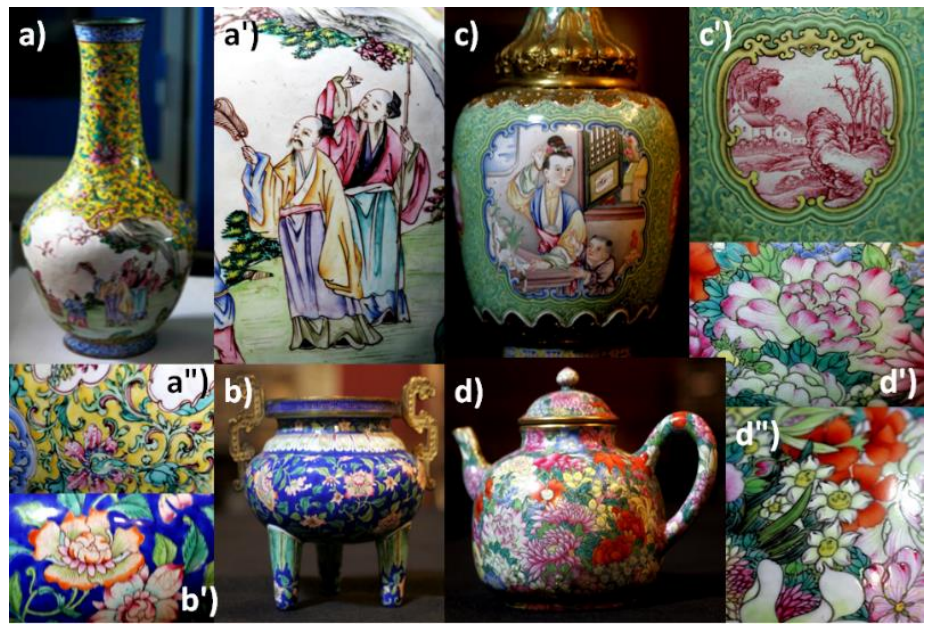

Figure 4. Chinese painted enamelled metal and porcelain wares: (a) R975 (18th century, a' and a' detail of the decor); (b) F1698C (18th century, b' detail); (c) F1440C (18th century, c' detail of the medallion); (d) F1429C (18th century porcelain, $\mathrm{d}^{\prime}$ and $\mathrm{d}^{\prime \prime}$ details).

The precision and quality achieved by the decoration of painted enamels is comparable to those obtained with European miniatures on ivory, paper [32] or enamelled watches [24] as well as the best productions of Limoges enamels $[13,25,26]$. It is important to note that the pair of ewers (F1467.1 and F1467.2, Figure 2) is decorated both with cloisonné and painted enamels. Furthermore, techniques of painting are different for the ewers and some of the painted enamelled artefacts presented in Figure 3. In the latter group, black lines delimit most of the coloured areas, as in the case of painted porcelains (F1341C, Figure 3; F1429C, Figure 4). A wide use of pink colour is also noted for the decors. The other set of painted enamelled artefacts such as the F1341C porcelain vase (Figure 3) and the R957 metal dish (Figure 3) show additional gilded decor. The technique of painting appears to be very similar for painted enamelled porcelains (F1341C, Figure 3; F1429C, Figure 4) and for enamelled metal artefacts by visual examination. More information on painted enamelled porcelains can be found in a companion paper [35] and previous studies of huafalang (actually, the studied artefacts expected to be made at the Imperial Palace workshops) and falangcai (artefacts made with imported enamels or with similar enamels) painted porcelains $[27,28]$.

The R975 bottle (Figure 4a) was selected for pXRF analyses due to the reason that it displays a high number of coloured areas of painted enamels and a rather well flat vertical surface.

Four artefacts (Table 1) with the Qianlong reign mark and exceptional quality (dimension, refinement of the painting, marks) allowed their assignment to a production of the Qing Palace workshops. Stylistic analysis also led to assign four artefacts to the factories of Guangzhou province and the two porcelains to the Jingdezhen Imperial Factory.

Methods: On-site measurements were carried out non-invasively with mobile Raman and XRF set-ups. The complete description of the procedure used with HE532 Raman spectrometer (HORIBA Jobin-Yvon, Longjumeau, France) equipped with $300 \mathrm{~mW} 532 \mathrm{~nm}$ Ventus laser (Laser Quantum, Fremont, CA, USA), a Peltier cooled charge coupled device CCD detector (HORIBA Jobin-Yvon, Longjumeau, France)and a remote SuperHead ${ }^{\circledR}$ connected (HORIBA Jobin-Yvon, Longjumeau, France) by optic fibres to the laser and the spectrometer has already been given in previous studies [12,13,24,26-28]. A $\times 50$ long working distance microscope objective (NIKON France SAS, Champigny-sur-Marne, France) was used. Illumination power at the sample varied between $\sim 2 \mathrm{~mW}$ (black and dark hues) and $15 \mathrm{~mW}$ (white). Due to the edge filter and optic fibres, the spectral background has a complex shape with a slope up to $\sim 500 \mathrm{~cm}^{-1}$ and then the background becomes almost flat. A reliable signal could be measured starting from $\sim 80 \mathrm{~cm}^{-1}$.

Portable XRF ( $\mathrm{pXRF}$ ) measurements were performed using an Elio instrument (ELIO, XGLab Bruker, Milano, Italy) which consists of a miniature X-ray tube system with a Rh anode, and a large area 
silicon drift detector (SDD). The complete description of the procedure has recently been published [24]. It should be noted the information thickness during the analysis of the enamel is estimated to be $\sim 4 \mu \mathrm{m}$ at $\mathrm{Si} \mathrm{K}, 130 \mu \mathrm{m}$ at $\mathrm{Cu} \mathrm{K} \mathrm{K}_{\alpha}, 220 \mu \mathrm{m}$ at $\mathrm{Au} \mathrm{L} \mathrm{L}_{\alpha}$, and $2.5 \mathrm{~mm}$ at $\mathrm{Sn} \mathrm{K}_{\alpha}$. The measurement data were processed using the data reduction software provided by the factory, which enables automatic peak recognition supported by manual peak selection and checking.

\section{Results}

\subsection{Cloisonné Enamels}

Representative Raman and XRF spectra are shown in Figures 5-15.
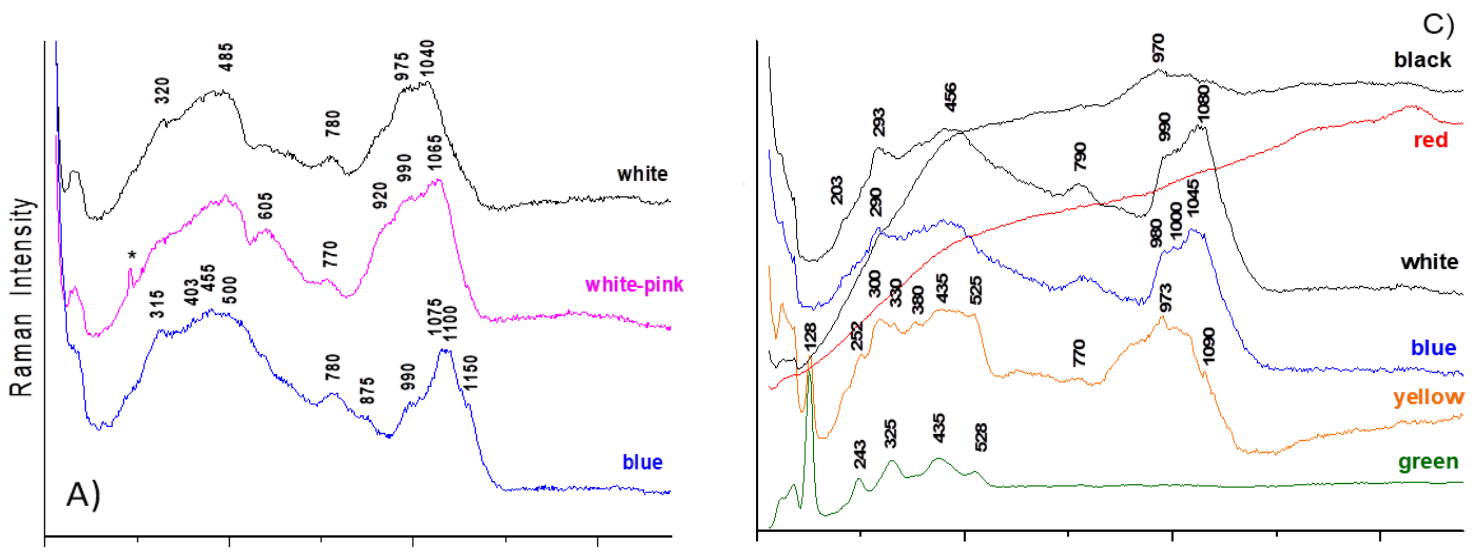

B)
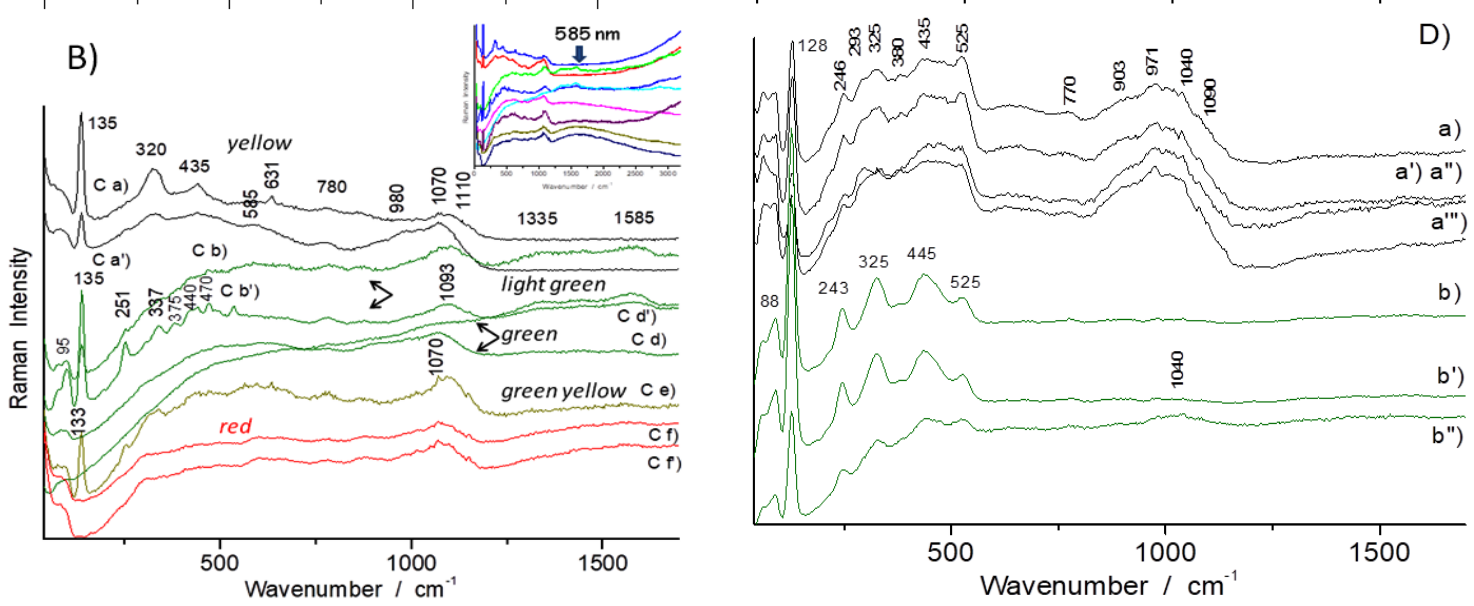

Figure 5. Representative Raman spectra recorded on the cloisonné enamelled F1448C (Kangxi period) tripod (left, A,B) and the F1501 (Qianlong period) bottle (right, C,D) for the different coloured areas. The small inserted graph shows the fluorescence peaking at $\sim 585 \mathrm{~nm}$ observed for red enamelled areas; (D) details; yellow: a to $\mathrm{a}^{\prime \prime \prime}$, green: $\mathrm{b}$ to $\mathrm{b}^{\prime \prime}$.

The results of the artefacts with cloisonné enamels will be first considered (photos: Figures 1 and 2; spectra; Figures 5 and 6, part of Figures 7 and 8). Cleaning of the analysed areas for elimination of dust and wax residues was not possible, except the effect provided by the laser beam. Indeed, due to the large thickness of the glassy cloisonné enamel (a few millimetres) which promotes microcracks, and the presence of many bubbles, some of which were opened by the final polishing, the enamelled surface retains many residues of organic compounds (waxes, oils) used previously to 'clean' and beautify the artefact which was then contaminated from the environment. Thus, the quality of the spectra obtained is variable, despite the fact that many spots have been measured. Consequently, the signature of carbon ( 1330-1570 $\mathrm{cm}^{-1}$ doublet) was first observed when the laser spot was focused at the surface. Spectra recorded under very short recording times show the carbon doublet (Figure 8). 
Burning and volatilizing the organic residues allows for collecting the Raman spectra of the enamel with a rather lower fluorescence background. Thus, assignment of the carbon signature observed is difficult. Its presence may be intrinsic due to the firing atmosphere during production or extrinsic due to the burning of dust and residues. The limitation of the spectral background is also important because the high number of bubbles and cracks degrade the optical quality of the material and hence the Raman signal. The background shape strongly depends on the colour of the analysed material due to the intrinsic fluorescence caused by organic residues or metal nanoparticles (see Figures 5 and 6 , bottom spectra as recorded from $\sim 50$ to $3200 \mathrm{~cm}^{-1}$ ). The absorption of the scattered light by the analysed material also determines the shape of the spectral background. Consequently, an apparent flat background is observed for blue matter while the background increases up to $\sim 500-1500 \mathrm{~cm}^{-1}$ using the Raman shift scale, actually $\sim 545-585 \mathrm{~nm}$ regarding the absolute scale, and then decreases for red matter [24].
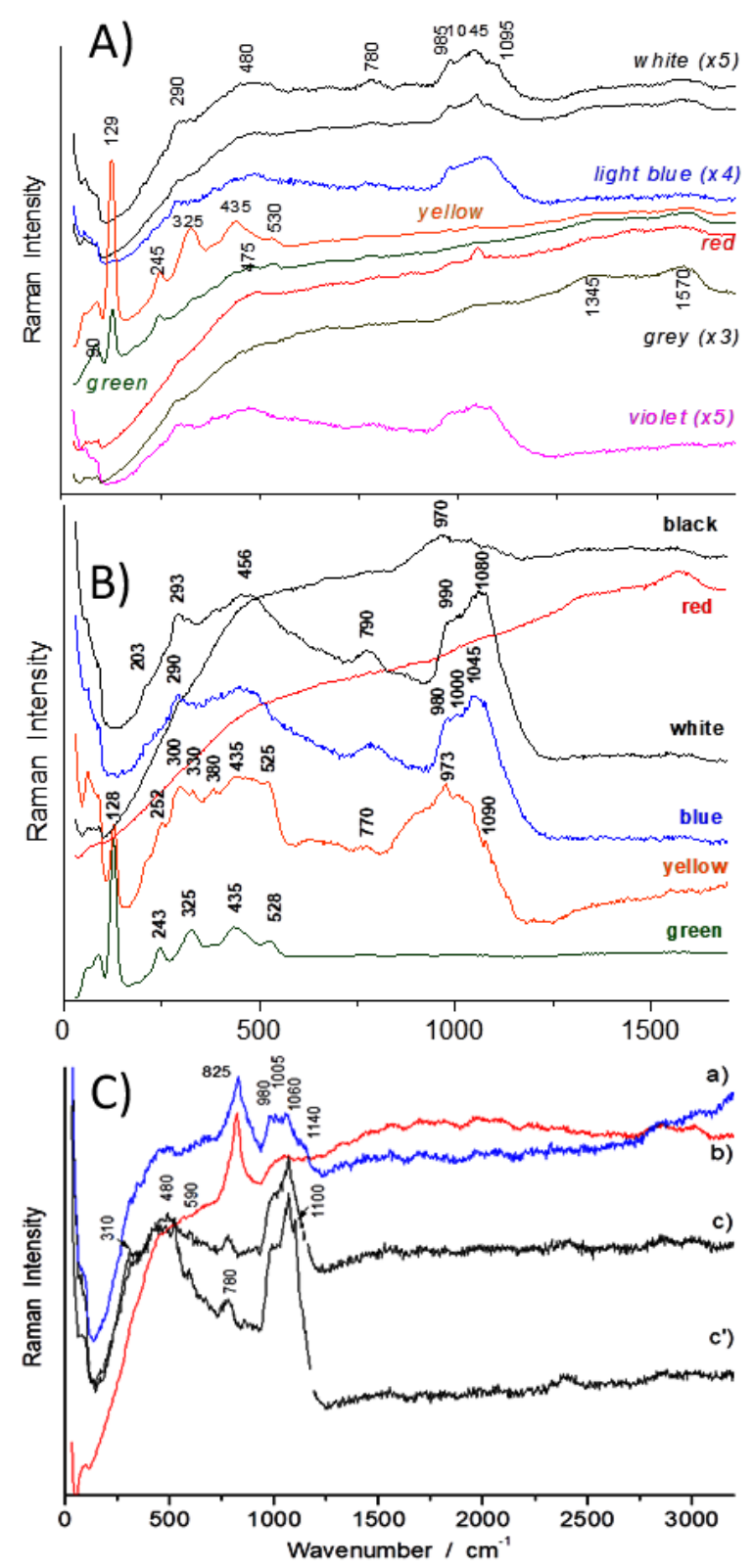

Figure 6. Representative Raman spectra recorded on F1735C (A, Qianlong period) and F1501 (B and C, Qianlong period) cloisonné enamelled wares. For the C Figure; a,b: blue enamelled areas; c, $\mathbf{c}^{\prime}$ : white enamelled areas. 


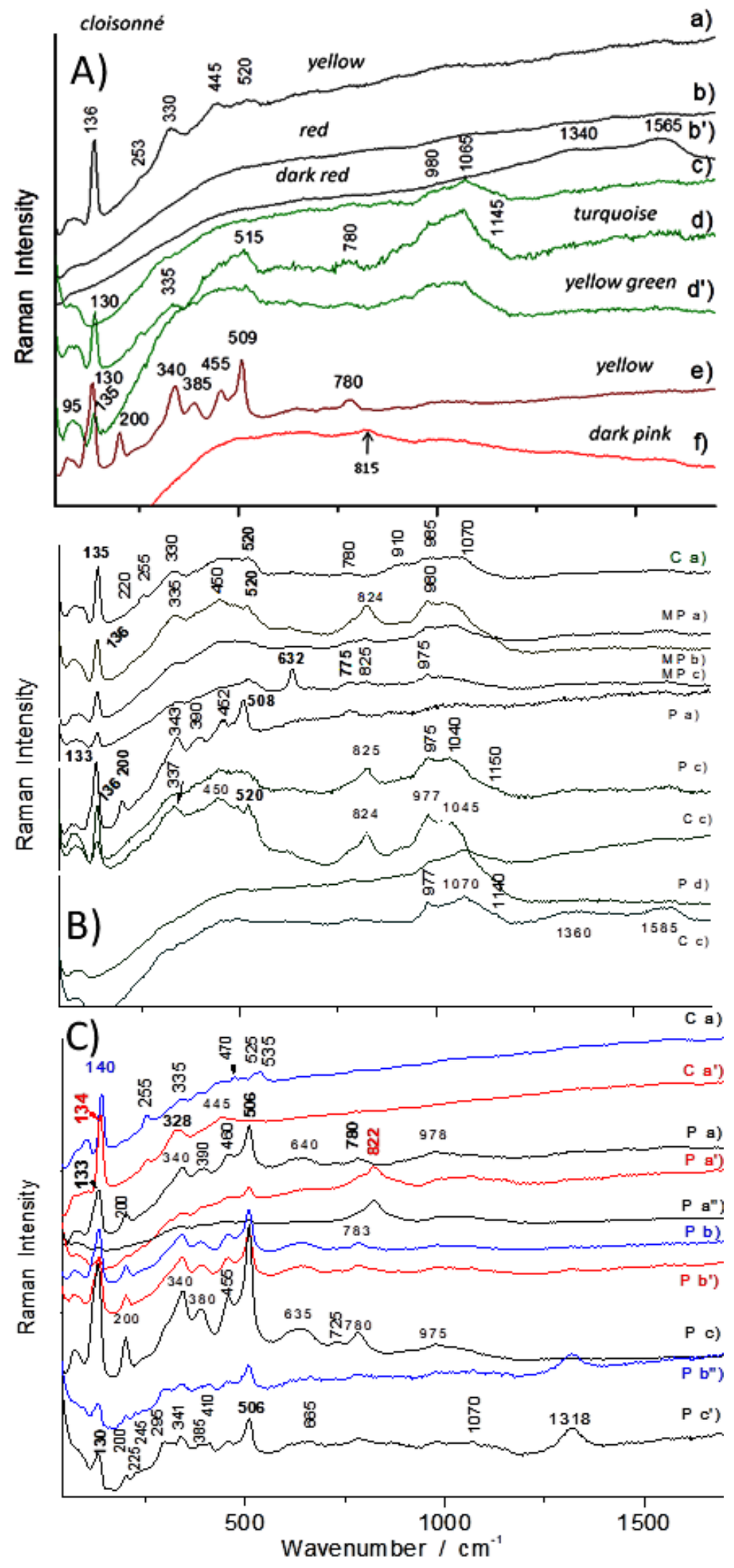

Figure 7. Representative Raman spectra recorded on the F1467.1 and F1467.2 ewers (Qianlong period): (A) cloisonné areas of different colours; (B) green cloisonné (spectra C) and painted (spectra P) areas (MP: painted areas of the medallion; two bottom spectra: turquoise areas); (C) yellow to orange cloisonné (C) and painted $(\mathrm{P})$ areas. 

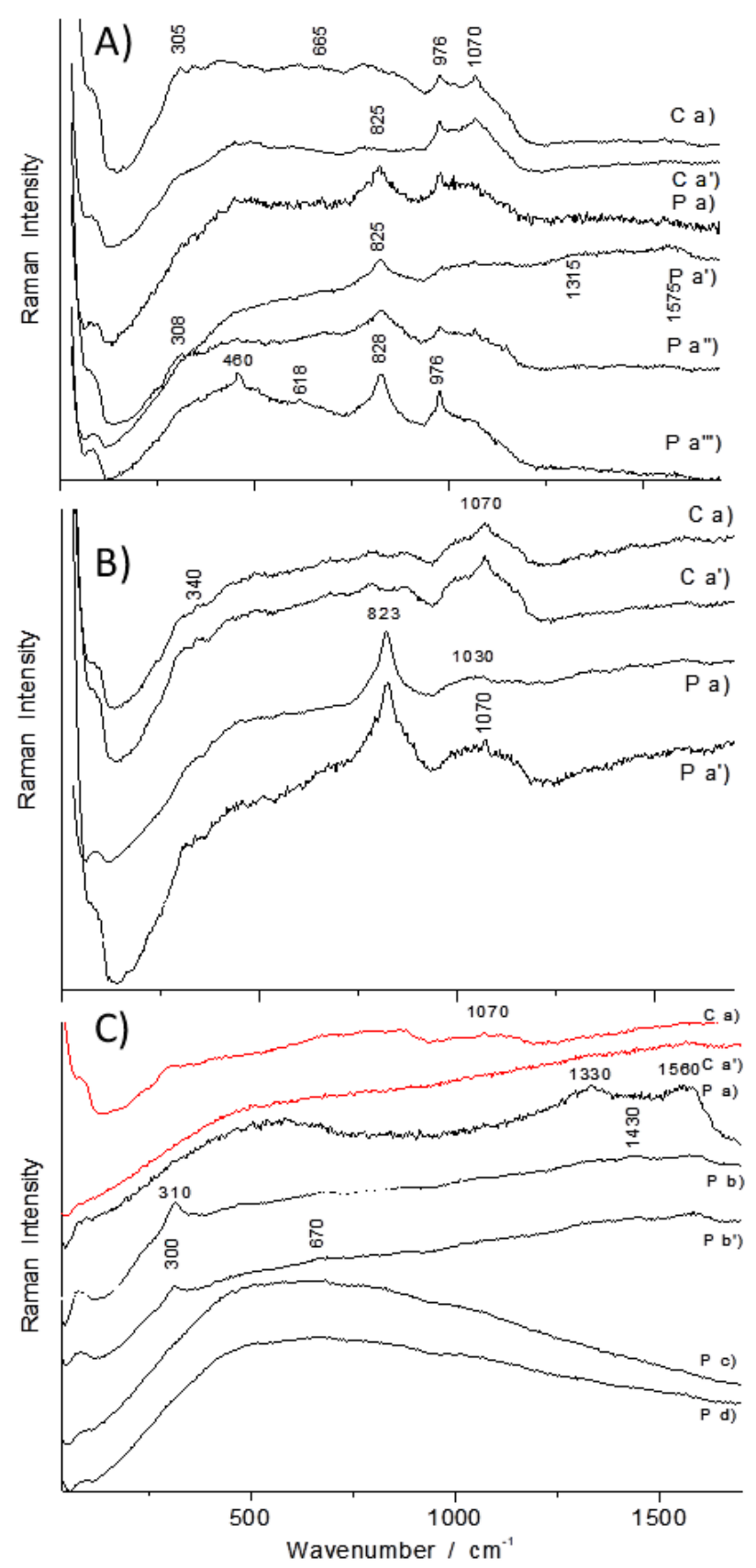

Figure 8. Representative Raman spectra recorded on the F1467.1 and F1467.2 ewers: (A) blue cloisonné (C) and painted (P) enamelled areas; $(\mathbf{B})$ white cloisonné $(\mathrm{C})$ and painted $(\mathrm{P})$ areas; $(\mathrm{C})$ black cloisonné $\left(\mathrm{Ca}, \mathrm{Ca}^{\prime}\right)$ and painted $\left(\mathrm{Pa}, \mathrm{Pb}, \mathrm{Pb}^{\prime}\right)$ and pink painted $(\mathrm{Pc}, \mathrm{Pd})$ areas. Spectra obtained on dark to black areas with very short counting times (a few seconds, (A) $\mathrm{Pa},(\mathbf{B}) \mathrm{Pa}^{\prime}$ and (C) $\mathrm{Pa}$ ) are compared with those obtained with standard recording times to demonstrate the absence of degradation).

\subsubsection{Opacifiers}

Raman spectra of the cloisonné enamels show several narrow and weak to very weak peaks which are characteristics of crystalline phases. Table 2 lists the identified crystalline phases with their characteristic Raman peaks which are consistent with previous Raman studies on Chinese enamelled artefacts $[12,34]$. The assignments will be summarized as follows.

The peak at 290 to $320 \mathrm{~cm}^{-1}$ located on the increasing spectral background (e.g., Figure 5A) is assigned to the signature of fluorite $\left(\mathrm{CaF}_{2}\right)$ as an opacifying agent. It is important to note that the 
Raman signature of $\mathrm{CaF}_{2}$ is poor, according to the rather ionic character of the $\mathrm{Ca}-\mathrm{F}$ bond. The use of fluorite in glass opacification is known to be a Chinese innovation which can be traced back to the Tang Dynasty (618-907 AD) [12,33,34]. Fluorite was also typically used in cloisonné enamels, starting from the 15th century [12]. Downshift of the wavenumber of the pure fluorite signal expected at $322 \mathrm{~cm}^{-1}$ (e.g., Figure 6) probably arises from the steep increasing background as well as some possible partial substitution of calcium with barium. The presence of barium in the enamels may be due to the occurrence of barium mineral impurities in the lead ores used in the making of lead-based enamels (see further) or deliberate addition of barium as a flux [39,40]. Confirmation should be carried out by elemental analysis. Lead glass with significant barium content is recognized as a specific Asian glass tradition dating back as early as the Warring States period (475-221 BC) in China [41].

In the blue enamelled areas, the Raman signature of the glassy silicate matrix was mainly observed, indicating the use of $\mathrm{Co}^{2+}$ ions for achieving blue colour (see further) [2]. The strong and rather broad $\sim 825 \mathrm{~cm}^{-1}$ peak observed in the blue enamel of one artefact (the F1501 bottle) corresponds to the As-O stretching mode which suggests the precipitation of lead arsenate apatite in lead-based enamel matrix (Figure 6C). This phase with the general formula $\mathrm{Na}_{1-\mathrm{x}-\mathrm{y} / 2} \mathrm{~K}_{\mathrm{x}} \mathrm{Ca}_{\mathrm{y}} \mathrm{Pb}_{4}\left(\mathrm{AsO}_{4}\right)_{3}$ may display a range of solid solution compositions with $\mathrm{Ca}, \mathrm{K}$ and $\mathrm{Na}$ arising from the fluxes used in the enamels $[13,28-30,42,43]$. Lead arsenate apatite is a typical phase found in 17th-century European glassy artefacts such as blue-and-white soft-paste porcelains and Limoges enamels, due to the use of European cobalt ores rich in arsenic $[13,27,28,44]$. The presence of this band may also be due to the deliberate addition of lead arsenate opacifier to adjust the hue. A similar feature was also previously identified in an 18th-century Chinese cloisonné enamelled artefact [12].
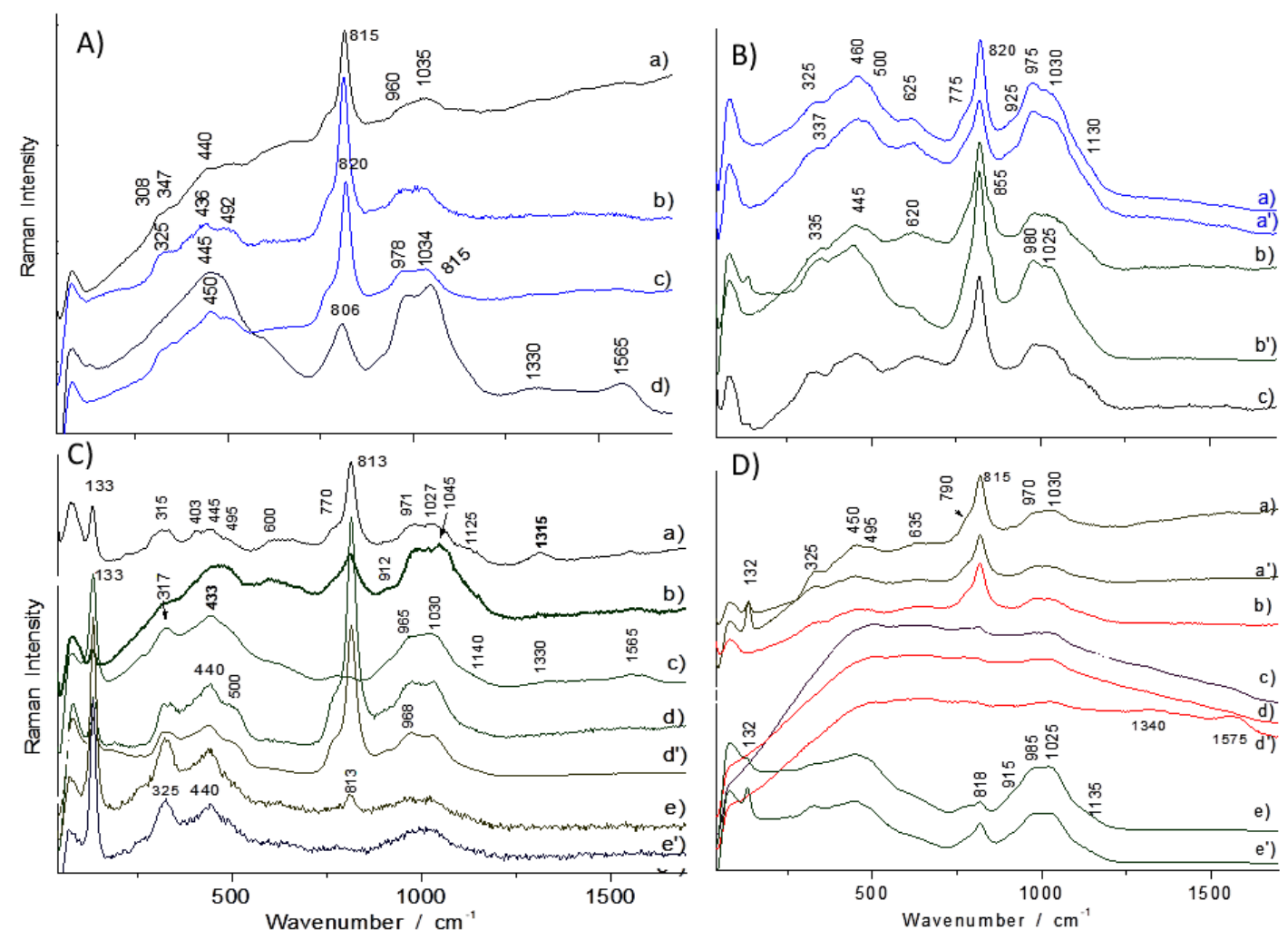

Figure 9. Representative Raman spectra recorded on R957 (left, A,C, mid 18th c.) and R958 (right, B,D, 2nd half of 18th c) dishes: (A,B) white $\left(\mathrm{a}, \mathrm{a}^{\prime}\right)$ and blue $\left(\mathrm{b}, \mathrm{c}, \mathrm{b}^{\prime}\right)$ and dark blue (d) areas; (C,D) yellow and green areas (see text); R958: spectra c, d and d' for red areas included. Noisy spectra are obtained with very short recording time to prevent any change due to local heating. 

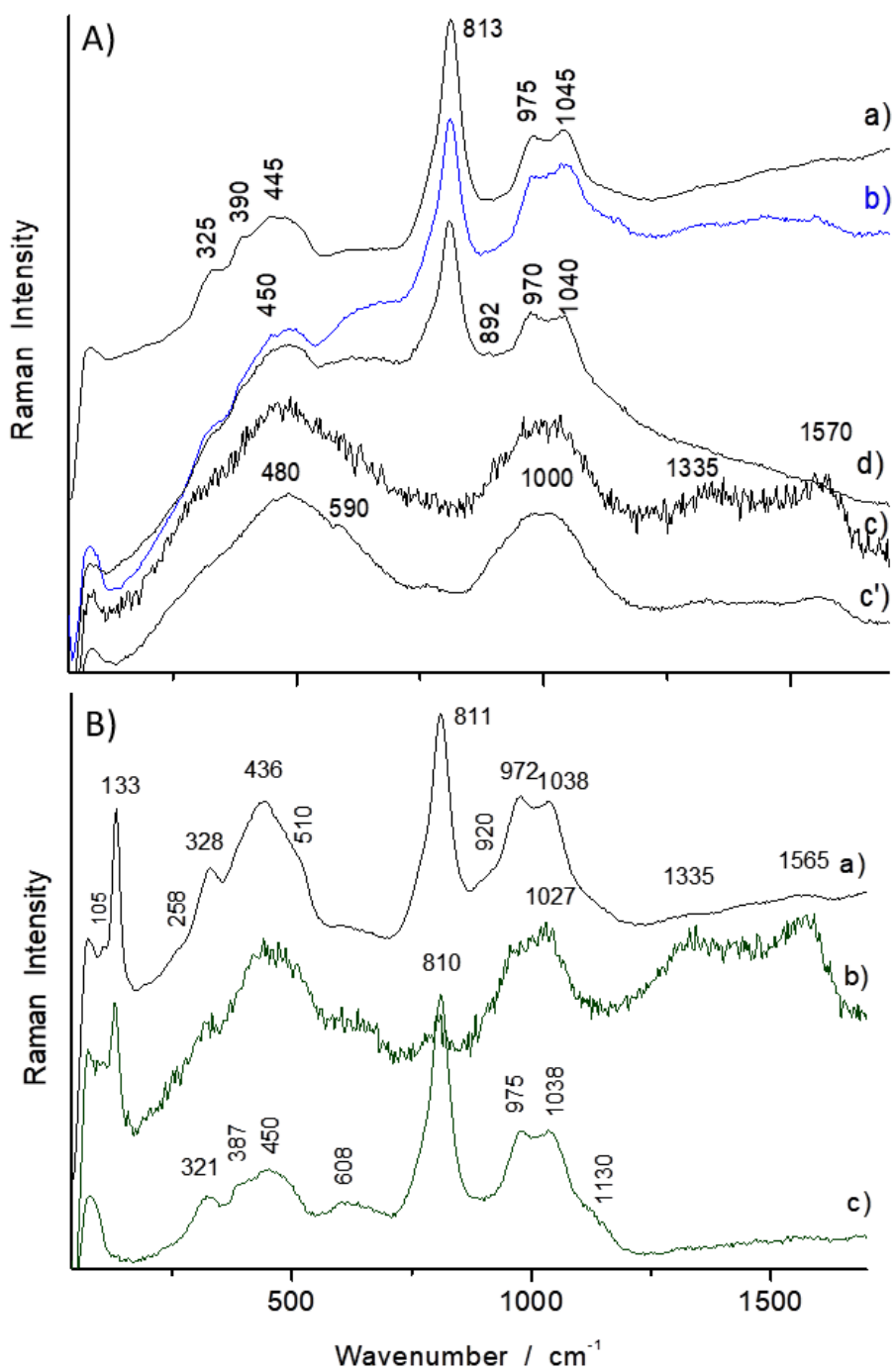

Figure 10. Representative Raman spectra recorded on the R975 bottle (2nd half of 18th century): (A) white (a), blue (b), pink (d) and black (c, $\left.c^{\prime}\right)$ enamelled areas; (B) yellow (a,b) and green/turquoise (c) enamelled areas (noisy spectra are obtained with very short recording time to control that no change due to local heating takes place, except disappearance of carbon signal to some extent).

A more surprising feature is related to the detection of cassiterite which was found in the yellow and greenish yellow (light green) areas of the F1448C tripod with 631-780 $\mathrm{cm}^{-1}$ doublet (Figure 5B-left bottom, spectrum $\mathrm{C}$ a,e). The yellow pigment used in this artefact is the Naples yellow type which here is the tin-rich lead pyrochlore (see further) and it is possible that excess tin in the pigment had led to the precipitation of cassiterite. In our previous study of Chinese artefacts dating to the 17th to 19th centuries, cassiterite was also identified in some of the yellow cloisonné enamels, in which Naples yellow lead pyrochlore pigment variations were detected [12]. However, it is also likely that addition of tin had been made to adjust the hue, according to European recipes or use of imported ingredients. In this case, this point is an argument to consider that this artefact dating to the Kangxi reign had been made with the guidance of Jesuit missionaries. It is also noteworthy to mention that in our previous study of huafalang porcelains [30] and regarding painted enamels analysed in this study, cassiterite was also detected in the light green enamel (see further). 


\subsubsection{Pigments}

More original features regarding crystalline phases were identified in the cloisonné enamels. In the blue enamel of the F1448C tripod (Figure 5A-top left), the Raman signature of a chromate phase can be attributed to a band at $\sim 875 \mathrm{~cm}^{-1}$ characteristic of the stretching mode of the chromate phase [45]. A rather strong band at $315 \mathrm{~cm}^{-1}$ and a smaller one at $403 \mathrm{~cm}^{-1}$ can also be assigned to its bending modes [46]. Chromium can be a minor element of cobalt ores such as many transition metals and the high intensity of Raman scattering of the $\mathrm{Cr}-\mathrm{O}$ bond makes the phase signature easily detected. A similar Raman feature was commonly identified in the black lines of famous Iznik pottery glazes with the use of chromite and/or spinel mixed ores [47]. Another similar feature has also been observed previously in the pink enamel of an 18th century Chinese cloisonné artefact [12].

The broad and strong $\sim 1310 \mathrm{~cm}^{-1}$ peak characteristic of the red enamelled areas coloured with hematite [48] (see porcelains, the F1429C teapot (Figure 12C; spectra b, $b^{\prime}$ ) and the F1341C vase (Figure 15C; spectra $\left.b, b^{\prime}\right)$ ), which is commonly observed in cloisonné enamels dating to the Ming period [12], was not detected in the cloisonné enamels studied. Hematite is a typical colouring phase of pottery bodies and has been used as a source of red colour since prehistoric times. However, its real use as a red pigment of glass and enamels has only been since the 15th century [2,49], particularly in Limoges [13,26] and Ming cloisonné [12] enamels. Red enamelled areas of cloisonné artefacts display a spectral background characteristic of coloration with metal nanoparticles (see e.g., the F1501 bottle; Figure 6B, and further), as observed for 17th-18th century French enamelled watches [24] and 18th century French porcelain and faience [2].

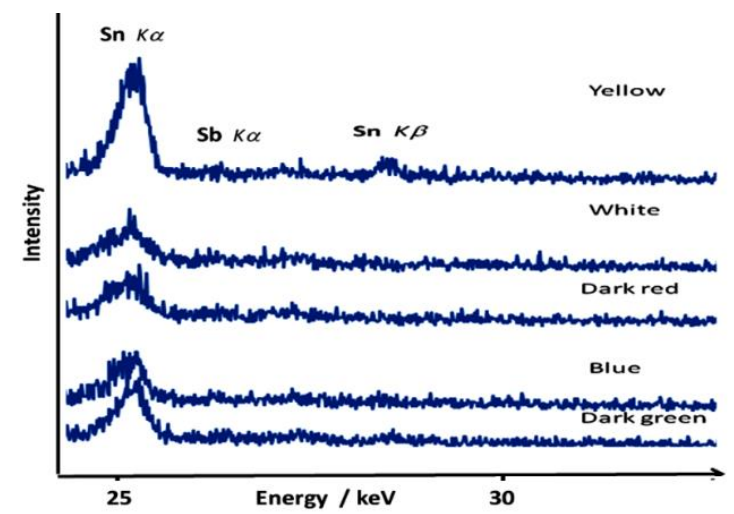

(a)

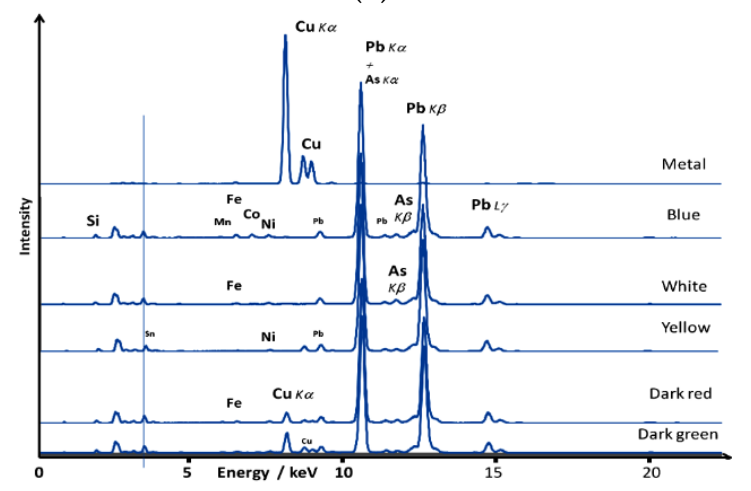

(b)

Figure 11. Representative portable $X$-ray fluorescence spectrometry (pXRF) spectra recorded on the R975 bottle for the metal and enamelled areas with different colours. A zoom of the region showing Sn and $\mathrm{Sb}$ elements is given in a). 

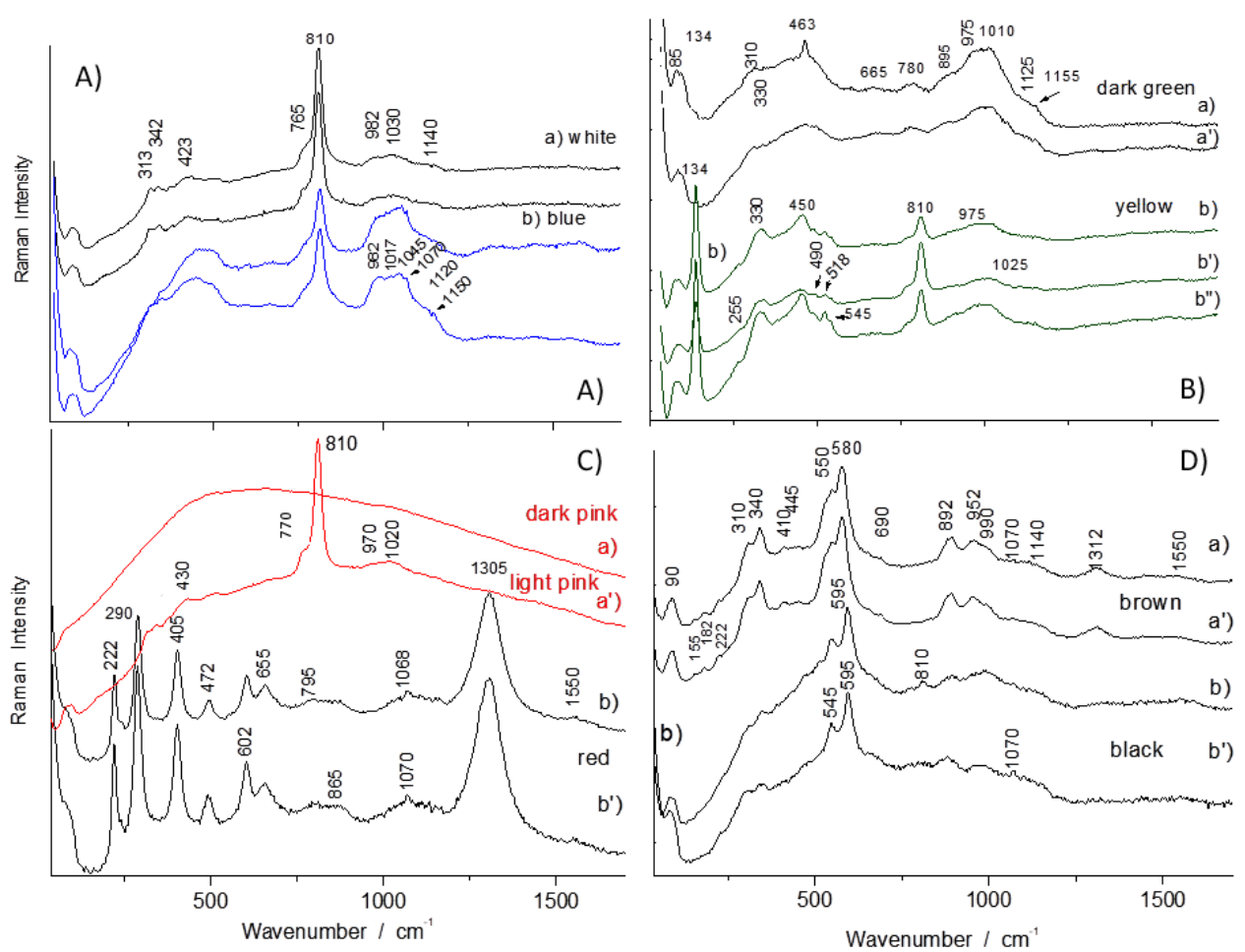

Figure 12. Representative Raman spectra recorded on the F1429C teapot porcelain (Qianlong period) for white (left, $\mathbf{A}, \mathrm{a}$ ), blue (left, $\mathbf{A}, \mathrm{b}$ ), dark green (right $\mathbf{B}$, a and $\mathrm{a}^{\prime}$ ), yellow (right, $\mathbf{B}, \mathrm{b}$ to $\mathrm{b}^{\prime \prime}$ ), pink (left, C, a and $\mathrm{a}^{\prime}$ ), red (left, C, b and b'), brown (right, D, a and $\mathrm{a}^{\prime}$ ) and black (right, D, b and b') enamelled areas.

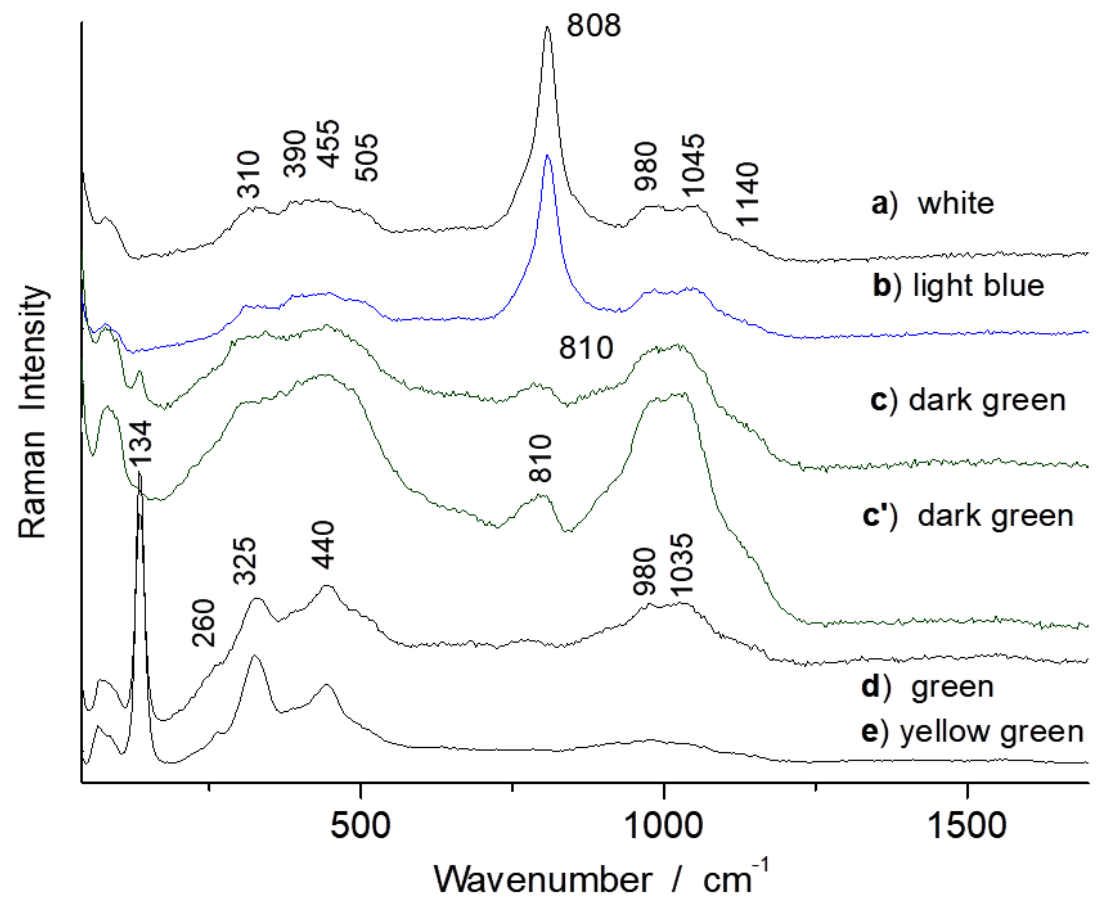

Figure 13. Representative Raman spectra recorded on the F1698C tripod (Qianlong period) for different coloured areas. 

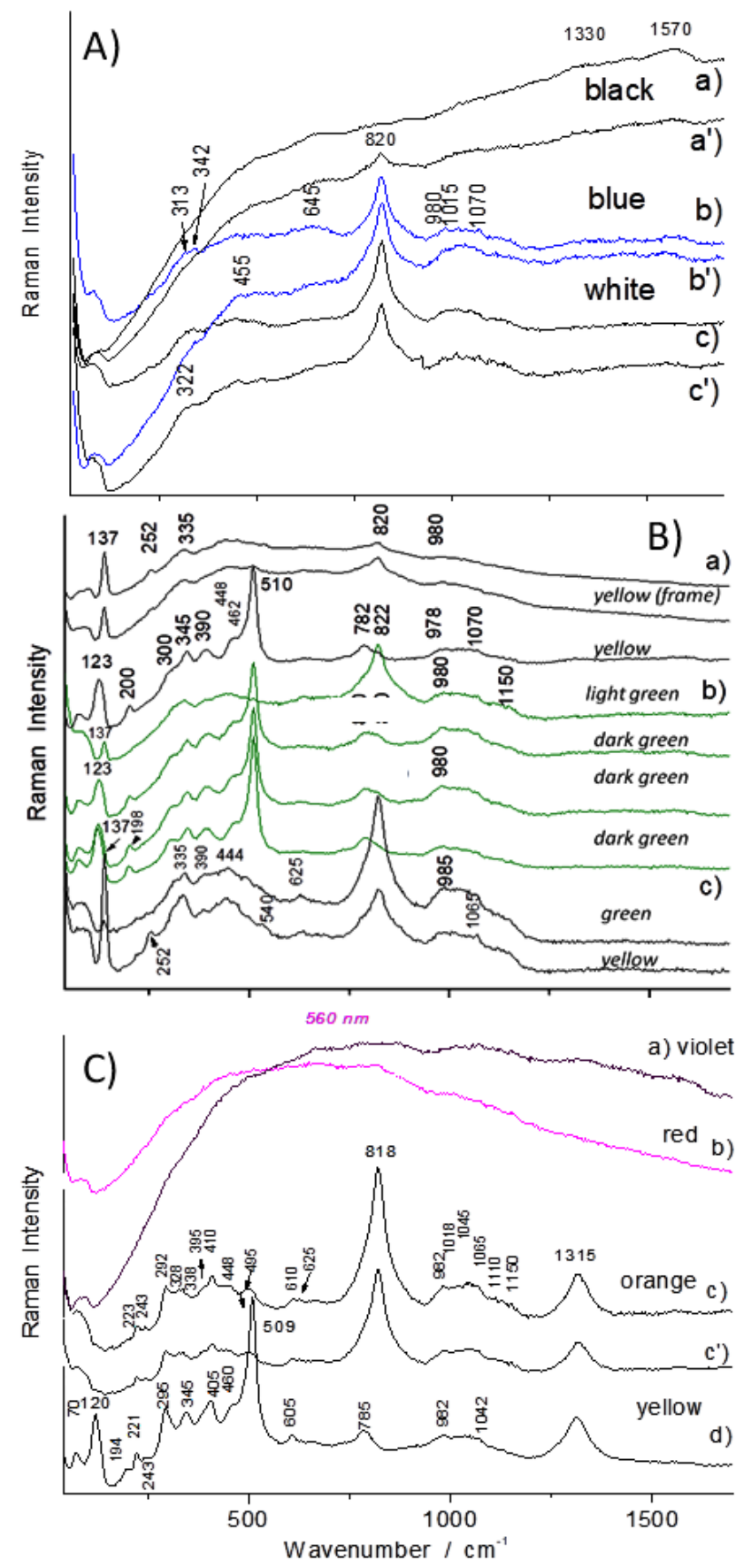

Figure 14. Representative Raman spectra recorded on the F1440C bottle (Qianlong period) for different coloured areas: white and blue (A), yellow and green (B) and special colours (C).

Particular attention should be paid to the yellow and green enamelled areas in which the characteristic Raman signature of Naples yellow lead pyrochlore was recorded (Table 2, e.g., Figure 5). Naples yellow is used here as a general pigment class covering a wide range of lead pyrochlore solid solutions $\left(\mathrm{Pb}_{2-\mathrm{x}} \mathrm{M}_{\mathrm{x}}^{\prime} \mathrm{M}_{2-\mathrm{y}} \mathrm{M}_{\mathrm{y}}^{\prime \prime} \mathrm{O}_{7-\delta} ; \mathrm{M}^{\prime}=\right.$ rare earth; $\mathrm{M}, \mathrm{M}^{\prime \prime}=\mathrm{Sn}, \mathrm{Sb}, \mathrm{Si}, \mathrm{Fe}, \mathrm{Zn}$, etc.). Naples yellow type pigments had been used as a colorant of glass and glazes since antiquity [50,51]. Their use was also confirmed in Byzantine glazed pottery [52], then continued with the onset of the Renaissance to later periods as a major pigment of ceramic glazes (majolica) and glasses as well as paintings [53-62]. Consequently, due to the strong characteristic Raman signature easily obtained (due to the very high polarizability of the $\mathrm{Pb}-\mathrm{O}$ bond) and wide range of compositions accepted by the pyrochlore structure 
which can be used as the specific signature of a workshop, many analytical studies have dealt with this pigment class up to now $[12,13,24,26-30,36-38,50-62]$.
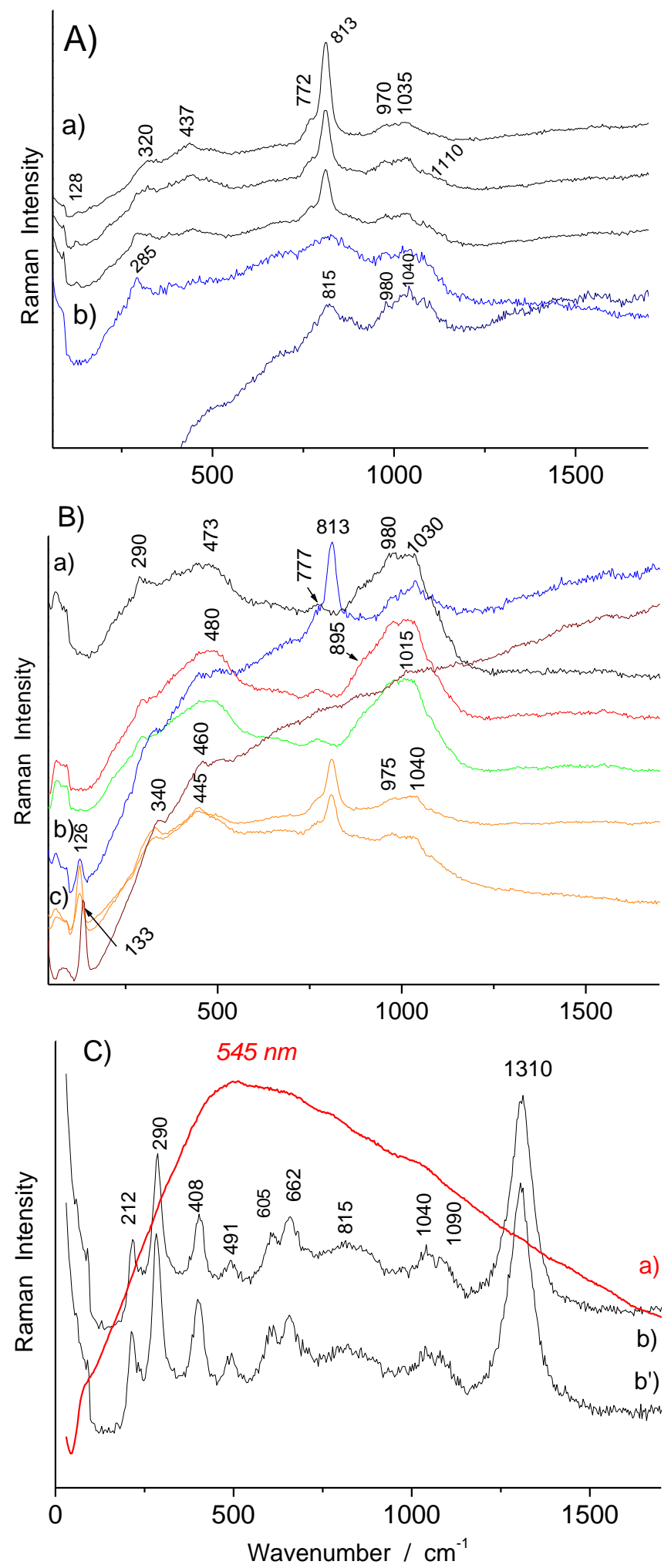

Figure 15. Representative Raman spectra recorded on the F1341C porcelain vase (Qianlong period) for different coloured areas: (A) white (a) and blue (b); (B) green (a) and yellow (b,c); (C) orange (a) and red $\left(b, b^{\prime}\right)$. 
Table 2. Crystalline phases identified in the cloisonné enamels (strongest; shoulder; L/l: light).

\begin{tabular}{|c|c|c|c|c|c|}
\hline Phase & $\begin{array}{c}\text { Characteristic Raman } \\
\text { Peaks }\left(\mathrm{cm}^{-1}\right)\end{array}$ & Refs. & Artefact & Colour & Remarks \\
\hline \multirow{11}{*}{$\begin{array}{l}\text { Naples } \\
\text { Yellow lead } \\
\text { pyrochlore }\end{array}$} & $95(?), \underline{135}, 251,337,375,470$ & \multirow{11}{*}[24,58-62]{} & F1448C & L.green & Complex Sb-Sn \\
\hline & $\underline{135}, 320,435$ & & F1448C & Yellow & Sn-rich \\
\hline & $\underline{128}, 243,325,445,525$ & & F1501 & Green & Sn-rich \\
\hline & $\underline{128}, 246,325,380,435,525$ & & F1501 & Yellow & Complex Sb-Sn \\
\hline & $\underline{129}, 245,325,435,530$ & & F1735C & Yellow & Sn-rich \\
\hline & $\underline{129}, 245,325,430,475,530$ & & F1735C & Green & Complex Sb-Sn \\
\hline & $\underline{136}, 253,330,445,520$ & & F1467.1 & Yellow & Sn-rich \\
\hline & $\underline{130}, 340,385,455, \underline{509}$ & & F1467.1 & Yellow g & Complex Sb-rich \\
\hline & $\underline{135}, 255,330,450,520$ & & F1467.1 & Green & Sn-rich \\
\hline & $\underline{140}, 255,335,380,470,525$ & & F1467.1 & Yellow-or & Complex Sb-Sn \\
\hline & $\underline{134}, 250,328,445$ & & F1467.1 & Yellow-or & Sn-rich \\
\hline Cassiterite & 631,780 & [2] & F1448C & $\begin{array}{l}\text { Yellow, green } \\
\text { yellow (l green) }\end{array}$ & - \\
\hline Lead arsenate & $\underline{825}$ & \multirow{2}{*}[13,27,28,44]{} & F1501 & Blue & As-rich cobalt \\
\hline apatite & 815 & & F1467.1 & Dark pink & Colloidal $\mathrm{Au}^{\circ}$ \\
\hline Phosgenite & $\underline{1045}$ & [63] & F1735C & $\begin{array}{l}\text { White } \\
\text { Red }\end{array}$ & $\begin{array}{c}\text { Corrosion } \\
\text { product/restoration? }\end{array}$ \\
\hline Chromate & $315,403,875$ & {$[45,46]$} & F1448C & Blue & - \\
\hline
\end{tabular}

Due to the high resolution of human eyes (a few microns), pigment grains must be very small to make homogeneous coloured areas. Consequently, compositional analysis of the artefacts must be performed at the very local scale by usually invasive/destructive techniques to discriminate between the composition of the pigment and that of the glassy matrix. In this study, very good spectra with a rather flat background were recorded (see Figure 5D, spectra $b$ to $b^{\prime \prime}$ ) when the laser spot diameter is sufficiently small to be close to that of pigment grains (up to $\sim-10 \mu \mathrm{m}$ and $1-2 \mu \mathrm{m}$ along $\mathrm{Z}$ axis perpendicular to the glass surface) as a function of the definition of light distribution (using $\times 100$ and $\times 200$ microscope objectives, respectively). On the contrary, if the grain size is much smaller (especially in the submicronic scale), crystallinity may be affected, and the specific pigment signature mixed with that of the glassy matrix is then detected (Figure 5D, spectra a to a"'). The first case arises when pigments are prepared separately and then added to the enamel precursor. The second case occurs when the pigment grains are very small, for instance when the saturation limit is exceeded and leads to a homogeneous precipitation. In this framework, Raman microspectroscopy as a non-invasive technique has the great advantage to record specifically the signature of the pigment and the glassy matrix. At least, three types of Naples yellow lead pyrochlore pigments are distinguished in the literature by Raman scattering and observed in the studied artefacts with the following subgroups:

(i) a first type characterised with a low-wavenumber strongest peak at $\sim 128-129 \mathrm{~cm}^{-1}$ and peaks of lower intensity at $\sim 245, \sim 325,435$ and $\sim 525 \mathrm{~cm}^{-1}$ (see e.g., Figure 5D right);

(ii) a second type with the strongest peak at $\sim 135-140 \mathrm{~cm}^{-1}$ and peaks of lower intensity at $\sim 320-335$, $\sim 440-450$ and $\sim 520 \mathrm{~cm}^{-1}$ (see e.g., Figure 7A,C);

(iii) a third one displaying similar features but with additional low intensity peaks at $\sim 375, \sim 470 \mathrm{~cm}^{-1}$ (Figure 5B left);

(iv) a fourth one displaying similar features with the others but with an additional strong component at $\sim 510 \mathrm{~cm}^{-1}$ with its intensity being similar with that of the low wavenumber one at $\sim 135 \mathrm{~cm}^{-1}$ (Figure $7 \mathrm{~A}, \mathrm{C}$ ). This strong low wavenumber peak arises from the vibration of $\mathrm{Pb}^{2+}$ ions and its 
wavenumber position both depends on the composition and firing temperature [36-38,53-62]: the peak wavenumber decreases when the firing temperature increases.

Studies of $\mathrm{Sn}-\mathrm{O}$ and $\mathrm{Sb}-\mathrm{O}$ end members of these lead pyrochlore solid solutions have allowed Raman identification of $\mathrm{Sn}-\mathrm{O}$ and $\mathrm{Sb}-\mathrm{O}$ stretching modes (stretching modes are stronger in Raman spectra) [24,58-62]. Thus, differentiation between Sn-rich and Sb-rich Naples yellow can be effectively carried out by using their Raman spectra. Sb-rich pigment commonly shows strong components at $\sim 330 \mathrm{~cm}^{-1}$ and $\sim 505 \mathrm{~cm}^{-1}$ (Sb-O stretching mode) while Sn-rich pigment shows a $450 \mathrm{~cm}^{-1}$ component (Sn-O stretching mode). Furthermore, observation of a significant additional $\sim 470 \mathrm{~cm}^{-1}$ component may correspond to more complex pyrochlore solid solutions also containing zinc and iron [24]. According to the results of this study, it is suggested that most of the enamels analysed are Sn-rich. However, yellow cloisonné enamel of the F1467 ewers (Figure 7A) is Sb-rich while their other pigments are mostly Sn-rich. It should also be noted that these different signatures were obtained on the same artefact regarding the yellow and green areas. Furthermore, the peak observed at $\sim 95 \mathrm{~cm}^{-1}$ in some of the green to yellow enamelled areas at the limit of reliable detection may be assigned to the presence of lead oxide $(\mathrm{PbO})$ due to saturation of the glassy silicate matrix with lead $[12,13,28]$. In our previous study of Chinese cloisonné metal wares, similar Raman features were detected for the yellow enamels [12]. Even Raman spectra recorded on Roman mosaic tesserae show a variable intensity of the $\sim 130-140$ vs. $\sim 510 \mathrm{~cm}^{-1}$ band ratio, demonstrating the early use of different compositions of lead pyrochlore yellow pigment [51]. The scientific literature [36-38,52-62] agrees that controlled use of the different compositions first developed for the production of majolica, and then the complete palette was first identified in the enamels on metal of the 17th- to 18th-century French enamelled clocks and watches [24].

Narrow peaks in the range $\sim 965$ to $\sim 1150 \mathrm{~cm}^{-1}$ may correspond to stretching modes of calcium phosphate, lead chloride, calcium silicate and/or sulphate phases $[2,30,34,63,64]$. In the lack of their other characteristic narrow peaks which are less strong and thus not detected with a portable Raman set-up, accurate identification is difficult. However, the ca. $1050 \mathrm{~cm}^{-1}$ peak ( $\mathrm{C}-\mathrm{O}$ stretching mode) can be most reasonably assigned to phosgenite $\left[\mathrm{Pb}_{2} \mathrm{Cl}_{2} \mathrm{CO}_{3}\right]$ which may be a surface corrosion product of lead-rich glass most probably reacting with humidity in the environment [63]. This assignment is consistent with the use of a lead-rich composition in the glassy matrix of the enamel identified by the strong Raman components at $\sim 970$ to $990 \mathrm{~cm}^{-1}$ (Figures 5-7). A similar peak has already been observed and assigned to lead white $\left(2 \mathrm{PbCO}_{3} \cdot \mathrm{Pb}(\mathrm{OH})_{2}\right)$ [34]. Lead white is not a thermally stable pigment but it could have been used for restoration purpose. High quality spectra recorded at the laboratory and optical microscopy examination are required to discriminate.

\subsubsection{Glassy Matrix}

Raman spectra of the cloisonné enamels show a broad band between $\sim 900$ and $1100 \mathrm{~cm}^{-1}$ with various shoulders/components, characteristic of the $\mathrm{Si}-\mathrm{O}$ stretching mode of the silicate matrix of the glassy enamels (Table 3, Figures 5 and 6, part of Figure 7). Comparison of the specific Si-O stretching band components and $\mathrm{Si}-\mathrm{O}$ bending to stretching band area ratio helps to distinguish between different enamel compositions, as previously demonstrated empirically [65-68] and by Density Functional Theory (DFT) modelling [69]. Due to the complex spectral background observed when using mobile edge filtered Raman spectrometers, comparison of the $\mathrm{Si}-\mathrm{O}$ bending band is very much dependent on the signal intensity, and thus comparison is only valid if recording procedures are identical, such as in this study. Here, only the $\mathrm{Si}-\mathrm{O}$ bending band obtained on some of the blue or green coloured areas can be observed with good reliability. Low-wavenumber components $\left(900 \mathrm{~cm}^{-1}\right.$ shoulder, strong component at $\sim 970$ to $990 \mathrm{~cm}^{-1}$ ) indicate a low-polymerized (lead-based) glass network made of more or less connected $\mathrm{SiO}_{4}$ tetrahedron fired at lower temperatures [65-68] and this type of glass exhibits a stretching band stronger than the bending one. According to previous studies of Chinese cloisonné enamels [12] and representative glass types [65-68], four types of glasses either with lead-rich or lead-(earth)alkali compositions were identified for the artefacts analyzed (Table 3): lead-rich glass with 
the strongest component at ca. 970 to $980 \mathrm{~cm}^{-1}$ (Type I), lead-(earth)alkali glass with the strongest component at ca. 1030 to $1050 \mathrm{~cm}^{-1}$ (Type IIa), with rather similar intensity of ca. 975 and $1045 \mathrm{~cm}^{-1}$ components (Type IIb), with the strongest component at ca. 1065-1070 $\mathrm{cm}^{-1}$ (Type III) and with the strongest component at ca. $1080-1100 \mathrm{~cm}^{-1}$ (Type IV). Rather different types of glass compositions observed are consistent with a multi-firing process of the cloisonné enamels. For instance, yellow enamels show the $\mathrm{Si}-\mathrm{O}$ modes at lowest values (ca. $970-1020 \mathrm{~cm}^{-1}$ ) while blue and white enamels show them at the highest ones $\left(1040-1100 \mathrm{~cm}^{-1}\right)$.

Table 3. $\mathrm{SiO}_{4}$ stretching components of the cloisonné enamels analysed (strongest; shoulder).

\begin{tabular}{|c|c|c|c|}
\hline Artefact & Si-O Stretching Components $\left(\mathrm{cm}^{-1}\right)$ & Colour & Glass Type \\
\hline \multirow{5}{*}{ F1448C } & $900, \underline{975}, \underline{1040}, 1150$ & White & Lead-alkali IIb \\
\hline & $920,990, \underline{1065}$ & White pink & Lead-alkali III \\
\hline & $990,1100,1150$ & Blue & Lead-alkali IV \\
\hline & $980, \underline{1070}, 1110$ & L. green yellow & Lead-alkali III \\
\hline & 1000,1093 & Green & Lead-alkali IV \\
\hline \multirow{3}{*}{ F1735C } & $985, \underline{1045}, 1095$ & White, blue & Lead-alkali IIa \\
\hline & $980, \underline{1030}, 1100$ & Green & - \\
\hline & $980, \underline{1050}, 1100$ & Violet & - \\
\hline \multirow{5}{*}{ F1501 } & $990, \underline{1080}$ & White & Lead-alkali IV \\
\hline & $980,1045,1100$ & Blue & Lead-alkali IIa \\
\hline & $900, \underline{975}, 1040,1090$ & Yellow & Lead-rich I \\
\hline & $\underline{970}, \underline{1040}$ & Green & Lead-alkali IIb \\
\hline & $\underline{970}, 1030,1100$ & Black & Lead-rich I \\
\hline \multirow{3}{*}{ F1467.1 } & $980, \underline{1065}$ & Turquoise & Lead-alkali III \\
\hline & $910,985, \underline{1070}, 1150$ & Green & - \\
\hline & $975, \underline{1070}, 1145$ & Blue & - \\
\hline
\end{tabular}

\subsection{Painted Enamels}

\subsubsection{Opacifiers}

Crystalline phases identified in the painted enamels are listed in Table 4 and representative spectra are given in Figures 7-15. The characteristic band of the As-O bond $[24,28,43,62,70]$ was detected in most of the artefacts, such as in the yellow to green enamels of F1467 ewers (Figure 7), white, blue, green, yellow enamels of the R957 and R958 dishes (Figure 9), white, blue and green enamels of the F1698C tripod (Figure 13), and white, blue, green and orange enamels of the F1440C bottle (Figure 14). The signatures observed in these enamels display some variations. This is also observed for the painted porcelains analysed (Figures 12 and 15). The characteristic signature of lead (calcium) arsenate apatite with $\mathrm{Na}_{1-\mathrm{x}-\mathrm{y} / 2} \mathrm{~K}_{\mathrm{x}} \mathrm{Ca}_{\mathrm{y}} \mathrm{Pb}_{4}\left(\mathrm{AsO}_{4}\right)_{3}$ structure $[43,62,70]$ with a strong rather narrow peak at ca. 810 to $820 \mathrm{~cm}^{-1}$ and a shoulder at ca. 765 to $790 \mathrm{~cm}^{-1}$ is observed in most of the painted enamels (F1341C and F1429C porcelains, R975, R957 and R958 metal wares). A broader band, characteristic of another variant structure or nanosized/nanocrystalline apatite precipitate (disorder induced broadening) is also observed at wavenumbers between 806 and $825 \mathrm{~cm}^{-1}$ (R957, Figure 9, top left A-d, bottom left C-b; R975, Figure 10). The presence of this signature may again be related to the use of European cobalt sources rich in arsenic in the blue enamels in which $\mathrm{Co}^{2+}$ ions were used as well as green ones where the lead pyrochlore pigment was mixed with the same blue glassy matrix. The other coloured areas are more likely to contain the deliberate addition of arsenic to adjust the hue. 
Table 4. Crystalline phases identified in the painted enamels (strongest; shoulder; porcelain: in bold italics).

\begin{tabular}{|c|c|c|c|c|}
\hline Phase & $\begin{array}{l}\text { Characteristic Raman } \\
\text { Peak }\left(\mathrm{cm}^{-1}\right)\end{array}$ & Refs. & Artefact & Colour \\
\hline \multirow{10}{*}{$\begin{array}{l}\text { Lead arsenate } \\
\text { apatite }\end{array}$} & $775, \underline{813}-\underline{815}$ & \multirow{10}{*}[13,27,28,43,62]{} & $F 1341 C$ & White, blue, green, yellow, red \\
\hline & $765, \underline{810}$ & & F1429C & $\begin{array}{c}\text { White, blue, pink, yellow, green, } \\
\text { black }\end{array}$ \\
\hline & $\underline{810}$ & & F1698C & $\begin{array}{l}\text { White, light blue, green, dark } \\
\text { green }\end{array}$ \\
\hline & $\underline{820}$ & & F1440C & $\begin{array}{l}\text { Black, blue, white, light green, } \\
\text { green, yellow, orange, red }\end{array}$ \\
\hline & $\underline{810}$ & & F1440C & Dark green \\
\hline & 775,810 & & R975 & White, blue, pink, yellow, green \\
\hline & $775, \underline{815}$ & & R957 & White, blue, yellow, green \\
\hline & $\underline{805}$ & & R957 & Dark blue \\
\hline & $775, \underline{815}$ & & R958 & White, blue, yellow, green, red \\
\hline & $775-790, \underline{820-825}$ & & F1467.1 & White, blue, yellow, green \\
\hline Manganese oxides & 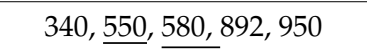 & {$[48,71]$} & $F 1429 C$ & Black, brown \\
\hline \multirow{12}{*}{$\begin{array}{l}\text { Naples Yellow lead } \\
\text { pyrochlore }\end{array}$} & $\underline{126}, 340,445$ & \multirow{12}{*}[12,24,58-62]{} & F1341C & Light green, yellow \\
\hline & $\underline{133}, 340,460$ & & F1341C & Yellow dot \\
\hline & $134,330,450,490,518$ & & $F 1429 C$ & Yellow \\
\hline & $134,260,325,440$ & & F1698C & Green, green yellow \\
\hline & $\underline{123}, 345, \underline{510}$ & & F1440C & Yellow, dark green \\
\hline & $\underline{137}, 252,335$ & & F1440C & Yellow (frame) \\
\hline & $\underline{133}, 328,436,510$ & & R975 & Yellow, green \\
\hline & $\underline{133}, 315,440$ & & R957 & Yellow, green \\
\hline & $\underline{132}, 325,450$ & & R958 & Yellow, green \\
\hline & $136,335,450,520$ & & F1467.1 & Green (S. Medallion) \\
\hline & $\underline{133}, 343,390,452, \underline{508}$ & & F1467.1 & Green \\
\hline & $\underline{133,340,380,455,506}$ & & F1467.1 & Yellow \\
\hline \multirow{5}{*}{ Hematite } & $212,290,408,490,605, \underline{1310}$ & \multirow{5}{*}[2,48,49]{} & $F 1341 C$ & Red-orange \\
\hline & $223,243,292,410, \underline{1315}$ & & F1440C & Orange, yellow \\
\hline & $225,410, \underline{1318}$ & & F1467.1 & Orange \\
\hline & $222,410, \underline{1312}$ & & $F 1429 C$ & Brown \\
\hline & $222,290,405,602,1305$ & & $F 1429 C$ & Red \\
\hline Quartz & $\underline{463}$ & [2] & $F 1429 C$ & Dark yellow green \\
\hline Copper oxide? & 300 & [2] & F1467.1 & Black \\
\hline Cassiterite & $\underline{632}, 775$ & [2] & F1467.1 & Green (S. Medallion) \\
\hline
\end{tabular}

Fluorite signature is possible in the F1467 ewers, in white and blue painted enamels (Figure 8A,B) with bumps at ca. 301 to $320 \mathrm{~cm}^{-1}$ [12], the peak being shifted by the complex background step.

Cassiterite with its characteristic doublet at ca. $632-780 \mathrm{~cm}^{-1}$ was only detected in the yellow and green enamelled areas of small medallions of F1467 ewers (Figure 7B-MPc). Observation of cassiterite especially in the green enamels suggests that cassiterite might have been deliberately added for achieving different green hues. This is technically significant in terms of the fact that the palette of green colour had long time been limited to turquoise $\left(\mathrm{Cu}^{2+}\right.$ in alkali glass), jade $\left(\mathrm{Cu}^{2+}\right.$ in lead-rich glaze) and one type of green (yellow pigment in blue coloured glass) [1,2]. Furthermore, the yellow 
pigment used here is Sb-rich Naples yellow type, which also points to deliberate addition of cassiterite to the enamels (see further).

\subsubsection{Pigments}

The presence of manganese oxide was only clearly detected for black and brown enamelled areas of F1429C tea pot which is a porcelain (not a metal ware) with the characteristic strong peak at 580-595 $\mathrm{cm}^{-1}[48,71]$ (Table 4, Figure 12D). On the other hand, hematite is found in red, yellow, orange and brown enamels of F1440C (Figure 14C), F1467 (Figure 7C) metal wares and F1429C (Figure 12C) and F1341C (Figure 15C) porcelains with different concentrations which demonstrate common use of similar pigments for metal and porcelain wares and use of hematite to adjust the hues (Table 4). very characteristic peak of quartz at $\sim 460 \mathrm{~cm}^{-1}$ was detected in yellow and green enamelled areas of F1429C porcelain, as observed for many glazes on hard-paste porcelains [2]. The $300 \mathrm{~cm}^{-1}$ peak in the black enamel may be assigned to the presence of copper oxide in F1467 ewers (Figure 8C, $\mathrm{Pb}^{\prime}$ ).

As in the case of cloisonné enamelled artefacts, different types of Naples yellow lead pyrochlore pigments were identified in the yellow and green painted enamels. Most of the enamels (R957, R958, R975, F1698C, F1440C) belong to the second type (see Section 3.1.2) with the low wavenumber peak at $\sim 133-140 \mathrm{~cm}^{-1}$ and lower intensity peaks at $\sim 320-335$ and $\sim 440-450 \mathrm{~cm}^{-1}$ which indicate a Sn-rich pyrochlore composition (e.g., Figures $9 \mathrm{C}$ and 13). Strong $\sim 120$ to 133 and $\sim 510 \mathrm{~cm}^{-1}$ peaks observed in F1440C (Figure 14B,C, yellow and dark green) and F1467 (Figure 7B,C, green and yellow) belong to the fourth type, representing the characteristic signature of Sb-rich complex lead pyrochlore composition. A low wavenumber $126 \mathrm{~cm}^{-1}$ peak is particularly observed for the light green-yellow enamelled area of the F1341C porcelain vase (Figure 15B). It is also worth mentioning that more than one type of lead pyrochlore compositions was used in the F1440C bottle dating to the Qianlong period.

\subsubsection{Glassy Matrix}

Table 5 compares the glassy silicate matrix signature of the painted enamels in the $\mathrm{SiO}_{4}$ stretching range. Three types of glass composition were observed, according to references [65-69]: lead-rich composition with the strongest component at $\sim 980 \mathrm{~cm}^{-1}$ (Type I), the lead-(earth)alkali composition with the strongest component at ca. 1020 to $1040 \mathrm{~cm}^{-1}$ (Type IIa) and intermediate composition with strong peaks both at ca. $965-980$ and $1025-1040 \mathrm{~cm}^{-1}$ or peaking in between $\left(1000 \mathrm{~cm}^{-1}\right)($ Type $\mathrm{IIb})$. The variety of composition is thus less than that observed for cloisonné enamels, indicating that the number of firings had been reduced. It is important to note the rather similar glassy matrices used for lead-based (over)glaze enamels and lead-alkali glaze of porcelain (F1429C) and metal wares (F1440C, F1698C).

\subsubsection{Glass Coloured with Gold Metal Nanoparticles}

A specific 'Raman' signature was observed for red, pink and violet enamelled areas (see Figure 7 (F1467; A,f), Figure 8 (F1467; C, Pc, d), Figure 9 (R958; D, c to d'), Figure 12 (F1429C porcelain; C,a,a'), Figure 14 (F1440C; C,a,b) and Figure 15 (F1341C porcelain; C,a). This implies a spectral background peaking at about $500-700 \mathrm{~cm}^{-1}$ (actually $500-600 \mathrm{~nm}$ ) characteristic of fluorescence in relation with the presence of metal $\left(\mathrm{Cu}^{\circ}\right.$ or $\left.\mathrm{Au}^{\circ}\right)$ nanoparticles used to obtain colour between red and violet/purple [24,72-79]. By comparison with previous studies on Perrot's ruby glass [29] and French enamelled watches [24], we can state that use of $\mathrm{Au}^{\circ}$ colloidal nanoparticles was carried out, as for Famille rose porcelain $[39,42-44]$. This signature is also accompanied by the band characteristic of the As-O stretching mode in many cases (see e.g., Figure 9D, R958). The presence of this band may indicate addition of arsenic to adjust the hue or the special technique of using arsenic salt for precipitation of colloidal gold to prepare the enamel precursor, which was first performed by the French glassmaker Bernard Perrot in the 17th century for the production of ruby glasses, some years before the Cassius purple preparation by Johann Kunckel [29,72-75]. 
Table 5. $\mathrm{SiO}_{4}$ stretching components of the painted enamels (strongest; shoulder).

\begin{tabular}{|c|c|c|c|}
\hline Artefact & Si-O Stretching Components $\left(\mathrm{cm}^{-1}\right)$ & Colour & Glass Type \\
\hline \multirow{3}{*}{ F1467.1 } & $980,1040,1070,1150$ & Green (medallion) & Lead-alkali IIb \\
\hline & $\underline{975}, \underline{1040}, 1130$ & Green & " \\
\hline & $\underline{980}, \underline{1040}$ & Yellow,red & Lead-reach alkali IIb \\
\hline \multirow{2}{*}{ R957 } & $978, \underline{1034}, 1130$ & White,blue & Lead-alkali IIb \\
\hline & $920,965,1030,1140$ & Yellow & Lead-alkali IIb \\
\hline \multirow{2}{*}{ R958 } & $970, \underline{1030}, 1130$ & Yellow,green,red & Lead-alkali IIb \\
\hline & $915, \underline{985}, \underline{1025}, 1135$ & Green & Lead-alkali IIb \\
\hline \multirow{3}{*}{ R975 } & $\underline{975}, \underline{1045}, 1130$ & White & Lead-alkali IIb \\
\hline & $920, \underline{972}, \underline{1038}, 1130$ & Yellow,green & Lead-alkali IIb \\
\hline & 1000 & Turquoise & Lead-rich $\mathrm{Ib}$ \\
\hline F1698C & $\underline{980}, \underline{1045,1140}$ & White,blue,green & Lead-alkali IIb \\
\hline \multirow{2}{*}{ F1440C } & $\underline{980}, 1070,1150$ & Yellow,green & Lead-alkali III \\
\hline & $980, \underline{1040}$ & Yellow & Lead-alkali IIa \\
\hline \multirow{4}{*}{ F1429C (porcelain) } & $980, \underline{1030}, 1140$ & White,blue & Lead-alkali IIa \\
\hline & $970, \underline{1020}$ & Light pink & Lead-alkali IIa \\
\hline & $900, \underline{975}, 1010,1130$ & Yellow & Lead-rich Ib \\
\hline & $900,975,1010,1125$ & Green & Lead-alkali IIb \\
\hline \multirow{3}{*}{ F1341C (porcelain) } & 970,1035 & White,blue & Lead-alkali IIb \\
\hline & 980,1030 & Green & Lead-alkali IIb \\
\hline & $\overline{1040,1090}$ & Red & Lead-alkali IIa \\
\hline
\end{tabular}

\subsection{Elemental Portable X-Ray Fluorescence Study}

Only one artefact, the R975 bottle was analysed by portable XRF. This artefact exhibits a large palette of colours and has a rather flat surface well adapted for on-site measurements. Representative XRF spectra are shown in Figure 11 and elements identified are listed in Table 6.

Table 6. The enamels analysed by pXRF (Major-minor-traces).

\begin{tabular}{cc}
\hline Colour & Elements \\
\hline Blue & $\mathbf{S i}, \mathbf{P b}-\mathrm{Co}, \mathrm{Fe}, \mathrm{As}, \mathrm{Sn}-\mathrm{Ni}, \mathrm{Mn}$ \\
White & $\mathrm{Si}, \mathbf{P b}-\mathrm{As}, \mathrm{Sn}-\mathrm{Fe}, \mathrm{Ni}$ \\
Yellow & $\mathrm{Si}, \mathbf{P b}-\mathrm{As}, \mathrm{Cu}, \mathrm{Sn}-\mathrm{Sb}, \mathrm{Fe}, \mathrm{Ni}$ \\
Dark red & $\mathrm{Si}, \mathbf{P b}-\mathrm{Cu}, \mathrm{Sn}, \mathrm{As}-\mathrm{Fe}, \mathrm{Ni}$ \\
Dark green & $\mathrm{Si}, \mathbf{P b}-\mathrm{Cu}, \mathrm{Sn}, \mathrm{As}-\mathrm{Fe}, \mathrm{Co}, \mathrm{Ni}, \mathrm{Mn}$ \\
\hline
\end{tabular}

Analysis of the metal body shows an alloy very rich in copper with traces of iron. A small amount of lead was also detected. All the enamels analysed also contain lead which had been deposited at the metal surface during the firing step due to the high volatility of lead oxide. Arsenic was also well detected in all the enamels with its $K_{\beta}$ peak in the spectrum since the $K_{\alpha}$ peak of arsenic with that of lead are superimposed at the same energy; confirmation was carried out with the software simulation and fitting process. Cobalt in association with iron, nickel, manganese was detected in the blue enamelled area. Observation of relatively high level of iron is consistent with the use of Asian cobalt ores but medium level of manganese and arsenic may correspond to mixing of both Asian and European cobalts, as also reported for Asian potters [36-38,76]. Tin was well detected in the yellow enamelled area together with traces of antimony, showing consistency with the Raman data. However, 
tin is also present in other coloured areas. In order to understand the presence of cassiterite in the yellow enamel, stratigraphic analysis on the cross-section is required (but this excluded in the absence of fragments coming from similar artefacts). Copper was measured in the dark green enamelled areas. The dark green enamelled area is thus coloured with $\mathrm{Cu}^{2+}$ ions since its Raman spectrum is characteristic of mainly the glassy phase with the As-O band at $810 \mathrm{~cm}^{-1}$ (Figure 10B a,b, arsenic whitening) in correlation with colouration by dispersing ions in the glassy matrix [2,24]. Some copper was also detected in the dark red area. It was not possible to detect gold ( $\mathrm{L}_{\alpha}-\mathrm{L}_{\beta}$ doublet expected between 9 and $12 \mathrm{keV}$ ) but in previous studies, Au has already been detected in painted enamels but in pink coloured areas $[33,34]$. Cuprite $\left(\mathrm{Cu}_{2} \mathrm{O}\right)$ can also be used as a red pigment for colouring glass [80] and also in association or not with copper nanoparticles, as supposed by some authors [81-85]. Thus, coloration with $\mathrm{Cu}^{\circ}$ nanoparticles is likely.

\section{Discussion}

According to the results of the analysed artefacts, some differences were observed regarding the glass compositions of cloisonné and painted enamels. The variety of composition appears to be larger for cloisonné enamels than the painted ones. This is in relation with the fact that the cloisonné technique requires many firing steps and firing temperatures since the decor is preserved by the metal foils forming walls and final polishing gives a similar gloss whatever the firing procedure is. By contrast, the technique of painted enamels involves mixing/superimposing different enamels with a limited number of firing cycles, which results in less difference regarding the compositions in order to avoid defects such as cracking or chipping. Interesting results also refer to identification of some pigments/phases in the analysed artefacts, not usually observed for Ming productions (Table 7):

(i) cassiterite $\left(\mathrm{SnO}_{2}\right)$, a very powerful white opacifier;

(ii) blue glass coloured (partially or totally) with arsenic-rich European cobalt and voluntary use of arsenic as a promoter of opacification, particularly with precipitation of lead arsenate apatite $\left[\mathrm{Na}_{1-\mathrm{x}-\mathrm{y} / 2} \mathrm{~K}_{\mathrm{x}} \mathrm{Ca}_{\mathrm{y}} \mathrm{Pb}_{4}\left(\mathrm{AsO}_{4}\right)_{3}\right]$;

(iii) colloidal gold ( $\mathrm{Au}^{\circ}$ nanoparticles), called Cassius' purple for purple to pink colour of European faience and porcelain enamels and ruby for glass, and characteristic of Qianlong Famille rose porcelains;

(iv) the different pyrochlores $\left(\mathrm{A}_{2-\mathrm{x}} \mathrm{A}_{\mathrm{x}}^{\prime} \mathrm{B}_{2-\mathrm{y}} \mathrm{B}_{\mathrm{y}}^{\prime} \mathrm{O}_{7-\delta}\right)$, usually called Naples yellow, namely the antimony-rich and tin-rich phases and the quaternary complex phase with variable content of zinc, silicon and iron.

Emergence of the significant/wide use of these colouring/opacification technologies and their duration in Europe are rather relatively well established regarding faience, porcelain and Limoges enamels but these studies cannot still allow us to have a precise statistical view at the scale of the decade, which is required to discuss precisely the technology transfer from Europe to Asia. Nevertheless, the following points can be stated.

\subsection{Cassiterite Opacification}

The first pigment with European origin is cassiterite which had been used as a glass opacifier in the Mediterranean World since the end of the Roman Empire [51]. It was at the origin of prodigious development of faience with the expansion of the Islamic World from the Middle East to Maghrib, Sicilia, al-Andalus (Spain and Portugal) and then Italy, France and Northern Europe. Limoges Renaissance enamels were also based on the use of cassiterite as opacifier $[13,26]$ and cassiterite was the opacifier of many soft-paste porcelain glazes [62,86-88]. The first evidence of the use of cassiterite in China comes from our previous study of huafalang porcelains of the Kangxi period $[27,35]$ and here in this work from green- and yellow-painted enamels of F1467 ewers, dating to the middle of the Qianlong reign. These ewers represent the most sophisticated artefacts of our corpus. Cassiterite was also detected in yellow and light green enamels of Kangxi F1448C cloisonné tripod, either due to a deliberate addition 
or precipitation of excess tin in the composition. This artefact is the oldest of the corpus, dating to the Kangxi reign. These findings are particularly interesting since the technique of cassiterite opacification was not used in China during the Ming Dynasty and was previously detected only in the light green painted enamel of a huafalang imperial bowl assigned to be made during the final period of the Kangxi reign (1715-1722) [27]. Detection of cassiterite is significant in terms of confirming the rareness of such a pigment in China and can be considered as a proof of the use of imported pigment(s) (light green directly ready to use or the ingredients to be mixed: 'cobalt ore', lead pyrochlore and cassiterite) in the artefacts mentioned dating as early as the Kangxi period or at least of the use of European recipes.

\subsection{Cobalt Ores' Provenance}

Blue enamelled areas exhibit the signature of lead arsenate apatite in most of the artefacts analysed, particularly the painted enamels. This phase has also been previously identified in Kangxi huafalang (G5250) and Famille rose (G3361) porcelains of the 18th century [27,28]. It is also typical of 17th and many 18th century French enamels [24]. Actually, in complex decors where superimposition of layers having different colours (the technique 'preferred' by European potters, see e.g., $[62,88]$ ) or mixing of colours (the technique 'preferred' by watch enamellers [24]) is present, it is difficult to prove by means of non-invasive mobile techniques that arsenic had not been deliberately added. In this case, examination of the stratigraphy of cut/polished shards is needed. However, for the artefacts in which the As-O stretching mode was detected, use of imported European cobalt in substitution of 'traditional' $\mathrm{Mn}$ - and Fe-rich cobalt ores (characteristic of Asian sources of cobalt), is likely. However, cobalt ores used during the Ming Dynasty were rich in manganese and iron and free of arsenic $[27,28,44,76]$. Furthermore, these signatures are observed simultaneously with the aforementioned characteristic pigments. Overall, it can be concluded that observation of the As-O signature in the blue enamels as well as the green ones (obtained by dispersing yellow pigment in blue coloured enamel) may be related to the use of cobalt sources with European origin, very rich in arsenic $[24,27,89,90]$ or deliberate addition of arsenic to control the colour [62,88]. Arsenic opacification was not used during the Ming Dynasty although arsenic opacification is a common technology of Italian (and French) 17th-century glassmakers and enamellers [24,29,57,86,87,91]. As deduced from pXRF measurements, mixing pigments of various origins to decrease the cost is likely, a practice carried out in Japan during the 17th and 18th century [36-38]. Thus, the artefacts mentioned above, for which arguments related to the use of European ingredients/recipes have already been well supported, should be particularly considered for future studies.

The Raman signature of the blue enamel of the Kangxi F1448C cloisonné tripod mainly shows the signature of the glassy matrix, with no evidence of the use of arsenic-rich cobalt, indicating the use of Asian cobalt as a continuation of the Ming Dynasty practices. This is consistent with the simultaneous use of both traditional and modern techniques in this artefact, according to its dating based on a stylistic approach to the end of Kangxi reign. The situation is less clear for the green enamels where a small band at $\sim 820 \mathrm{~cm}^{-1}$ is consistent with the use of European cobalt. Regarding the R957 dish, the As-O signature is observed in every enamels but in the blue one, shape of the signature is different than the others, being much broader. In that case, search of specific cobalt ore-associated elements such as $\mathrm{Ni}$, Bi, etc. by $\mathrm{XRF}$ is required to reach a more definitive conclusion.

Comparison of the Raman spectra of cloisonné and painted blue enamels of F1467 ewers (Figure 8A) shows the presence of lead arsenate apatite only in the painted enamel.

\subsection{Gold Nanoparticles}

Thirdly, the use of metal nanoparticles to obtain red to violet related colours in glass/enamels is also a technique of European origin [29,72-75,92,93]. Combination of fluorescence signature plus that of the As-O bond for dark pink cloisonné enamel of F1467.1 ewer (Figure 7A;f) is consistent with the use of Bernard Perrot's technique to prepare colloidal gold. Similar features are observed for the R958 dish (Figure 9D; spectra c,d, $\mathrm{d}^{\prime}$ ), the F1429C porcelain teapot (Figure 12C;a, $\mathrm{a}^{\prime}$ ), the F1440C porcelain 
bottle (Figure 14C;a,b) and the F1341C porcelain vase (Figure 15C;a). XRF measurements are again needed for confirmation but the preliminary results obtained are very consistent.

Table 7. Comparison between European and Chinese enamelling technologies, as evidenced from Raman studies (sh: shoulder).

\begin{tabular}{|c|c|c|c|c|c|c|c|}
\hline Criteria & $\begin{array}{c}\text { Main Raman } \\
\text { Peak }\left(\mathrm{cm}^{-1}\right)\end{array}$ & Artefact & Colour & Europe & Refs. & China & Refs \\
\hline \multirow{3}{*}{$\begin{array}{l}\text { Colloidal } \\
\text { gold }\end{array}$} & \multirow{3}{*}{$\begin{array}{l}\text { Background } \\
\text { peaking at } \\
\sim 500-600 \mathrm{~nm}\end{array}$} & Glass & \multirow{3}{*}{$\begin{array}{l}\text { Pink, } \\
\text { Red, } \\
\text { purple }\end{array}$} & $\begin{array}{l}\text { Perrot' ruby glass } \\
\text { mid } 17 \text { th century }\end{array}$ & [29] & Not studied & - \\
\hline & & $\begin{array}{l}\text { Enamel } \\
\text { on glaze }\end{array}$ & & $\begin{array}{l}\text { French soft-paste } \\
\text { porcelain and } \\
\text { faience, }>1 \text { st quarter } \\
\text { of } 18 \text { th century }\end{array}$ & {$[30,88]$} & $\begin{array}{c}\text { Famille rose } \\
\text { (Yongzheng reign } \\
\text { 1722-1735) }\end{array}$ & {$[28,35]$} \\
\hline & & $\begin{array}{l}\text { Enamel } \\
\text { on metal }\end{array}$ & & $\begin{array}{c}\text { Blois and Paris } \\
\text { watches, }>\text { mid-17th } \\
\text { century }\end{array}$ & [24] & Qianlong, F1467 & $\begin{array}{l}\text { This } \\
\text { work }\end{array}$ \\
\hline \multirow{3}{*}{ Cassiterite } & \multirow{3}{*}{635} & Glass & White & $\begin{array}{l}\text { Late Roman Empire } \\
\text { Perrot' glass } \\
\text { Mid-17th century }\end{array}$ & {$[29,51]$} & Not studied & - \\
\hline & & $\begin{array}{c}\text { Enamel } \\
\text { on glaze }\end{array}$ & $\begin{array}{l}\text { White } \\
\text { yellow }\end{array}$ & $\begin{array}{l}\text { Majolica 15th } \\
\text { century, }\end{array}$ & - & $\begin{array}{l}\text { huafalang, Kangxi, } \\
\text { G5250 (light green) }\end{array}$ & {$[27,35]$} \\
\hline & & $\begin{array}{l}\text { Enamel } \\
\text { on metal }\end{array}$ & $\begin{array}{l}\text { White } \\
\text { Yellow } \\
\text { green }\end{array}$ & $\begin{array}{c}\text { Limoges }<16 \text { th } \\
\text { century Blois and } \\
\text { Paris watches, } 17 \text { th } \\
\text { century }\end{array}$ & $\begin{array}{l}{[12,13,} \\
24]\end{array}$ & Qianlong, F1467 & $\begin{array}{l}\text { This } \\
\text { work }\end{array}$ \\
\hline \multirow{3}{*}{$\begin{array}{l}\mathrm{Pb}-(\mathrm{Sn}, \mathrm{Zn})-\mathrm{Sb} \\
\text { pyrochlore }\end{array}$} & \multirow{3}{*}{$130-140$} & Glass & Yellow & $\begin{array}{l}\text { Roman times Perrot' } \\
\text { glass, 17th century }\end{array}$ & {$[29,51]$} & Not studied & - \\
\hline & & $\begin{array}{l}\text { (Enamel } \\
\text { on) glaze }\end{array}$ & $\begin{array}{l}\text { Yellow } \\
\text { Green }\end{array}$ & $\begin{array}{l}\text { Majolica 15th } \\
\text { century }\end{array}$ & [53-61] & Qianlong, F1429C & $\begin{array}{c}\text { This } \\
\text { work,35 }\end{array}$ \\
\hline & & $\begin{array}{l}\text { Enamel } \\
\text { on metal }\end{array}$ & $\begin{array}{l}\text { Yellow } \\
\text { (Green) }\end{array}$ & $\begin{array}{c}\text { Limoges } 16 \text { th } \\
\text { century Blois and } \\
\text { Paris watches, 17th } \\
\text { century }\end{array}$ & $\begin{array}{l}{[12,13,} \\
24]\end{array}$ & $\begin{array}{l}\text { Cloisonné: Kangxi } \\
\text { reign F1448C Painted: } \\
\text { Qianlong G5068 (18th } \\
\text { c., Jingdezhen) G3361 } \\
\text { (Kangxi?, Jingdezhen) }\end{array}$ & $\begin{array}{l}\text { This } \\
\text { work }\end{array}$ \\
\hline \multirow{3}{*}{$\begin{array}{l}\mathrm{Pb}-(\mathrm{Sn}, \mathrm{Zn})-\mathrm{Sb} \\
\text { pyrochlore }\end{array}$} & \multirow{3}{*}{$\sim 140+510$} & Glass & Yellow & $\begin{array}{l}\text { Roman times Perrot' } \\
\text { glass, 17th century }\end{array}$ & {$[29,51]$} & Not studied & - \\
\hline & & $\begin{array}{l}\text { Enamel } \\
\text { on glaze }\end{array}$ & Yellow & $\begin{array}{l}\text { French soft-paste } \\
\text { porcelain 18th } \\
\text { century }\end{array}$ & [30] & $\begin{array}{l}\text { huafalang: Kangxi } \\
\text { G5250 }\end{array}$ & [27] \\
\hline & & $\begin{array}{l}\text { Enamel } \\
\text { on metal }\end{array}$ & Yellow & $\begin{array}{l}\text { Limoges } 17 \text { th-18th } \\
\text { century Blois and } \\
\text { Paris watches, 18th } \\
\text { century }\end{array}$ & $\begin{array}{l}{[12,13,} \\
24]\end{array}$ & $\begin{array}{c}\text { Cloisonné: Qianlong } \\
\text { F1467 }\end{array}$ & $\begin{array}{l}\text { This } \\
\text { work }\end{array}$ \\
\hline \multirow{3}{*}{$\begin{array}{l}\text { As-O } \\
\text { signature in } \\
\text { blue }\end{array}$} & \multirow{3}{*}{$815-820$} & Glass & Blue & $\begin{array}{l}\text { Perrot' glass } 17 \text { th } \\
\text { century }\end{array}$ & [29] & Not studied & - \\
\hline & & $\begin{array}{l}\text { Enamel } \\
\text { on glaze }\end{array}$ & Blue & $\begin{array}{l}\text { St-Cloud, Paris } \\
\text { Soft-paste porcelain } \\
17 \text { th century }\end{array}$ & - & $\begin{array}{l}\text { huafalang: Kangxi, } \\
\text { G5250 }\end{array}$ & $\begin{array}{c}{[27,30,} \\
43]\end{array}$ \\
\hline & & $\begin{array}{l}\text { Enamel } \\
\text { on metal }\end{array}$ & Blue & $\begin{array}{c}\text { Limoges } 17 \text { th } \\
\text { century Blois and } \\
\text { Paris watches, 17th } \\
\text { century }\end{array}$ & $\begin{array}{l}{[12,13,} \\
24]\end{array}$ & $\begin{array}{c}\text { Cloisonné: Qianlong } \\
\text { F1501 }\end{array}$ & $\begin{array}{l}\text { This } \\
\text { work }\end{array}$ \\
\hline \multirow{3}{*}{$\begin{array}{l}\text { Lead-arsenic } \\
\text { apatite }\end{array}$} & \multirow{3}{*}{820,780} & Glass & White & $\begin{array}{l}\text { Lattimo (Venice, 17th } \\
\text { century) }\end{array}$ & [57] & Not studied & - \\
\hline & & $\begin{array}{l}\text { Enamel } \\
\text { on glaze }\end{array}$ & White & Not observed & - & $\begin{array}{l}\text { G3361 (Kangxi?, } \\
\text { Jingdezhen) }\end{array}$ & [27] \\
\hline & & $\begin{array}{l}\text { Enamel } \\
\text { on metal }\end{array}$ & White & $\begin{array}{l}\text { Limoges 19th } \\
\text { century }\end{array}$ & {$[12,13]$} & Qianlong, F1440C & $\begin{array}{l}\text { This } \\
\text { work }\end{array}$ \\
\hline
\end{tabular}


Colloidal gold seems to have been first used for preparation of ruby glass. The first recipes had been given by Andreas Cassius, who described it in his treatise De Auro in 1685 [29,72-75,92,93]. In fact, the process of using gold in glass for achieving red-violet colour had already been mentioned by the chemists Johann Glauber and Andreas Libavius a few decades before and the process was also well described in a 15th-century Bolognese manuscript entitled Segreti per colori about pigment recipes for the painters [92,93]. Eighteenth-century versions of Antonio Neri's L'Arte Vetraria (1612) then describe a similar process for creating red-coloured glass by heating a gold powder until it turned purple. Gold nanoparticles are precipitated with the use of Sn or As ions from a gold solution in regal acid (aqua regia) and then incorporation of the obtained powder into the glass precursor before firing [93]. Besides gold, copper nanoparticles are also significant in terms of giving red colour [73], as observed in red Roman mosaic glass tesserae [50,51,94-96] and in the Late Roman Lycurgus cup [97]. Indeed, the large amount of copper also measured in the latter glass artefact suggests that gold contribution to red colour may not be so significant [73]. Geyssant [72] reports that in 1668, Bernard Perrot obtained the recipe from Marc Antoine Galaup de Chasteuil, a French alchemist, via his partners in the foundation of Orleans Glass factory, the marquise du Plessis-au-Chat and the Count de Bachimont, future husband of the marquise. Perrot's technology is the first documented use of colloidal gold based on arsenic both by text and elemental and spectroscopical analyses [29,72] and the recent study of 17th-18th century enamelled French watches shows that this technique was being used by watch workshops at the same time [24]. First use in China has only been identified during the Yongzheng reign $[27,28]$ for porcelains and Qianlong reign for metal wares in this study (e.g., F1467).

\subsection{Naples Yellow Lead Pyrochlore}

The last important conclusion can be drawn from the comparison of the different Naples yellow lead pyrochlore pigment compositions used to obtain different yellow and green enamel hues in the artefacts. At least three different types of Naples yellow pigment have been identified. All these compositions had commonly been used since the Renaissance for glass, faience and majolica as well as for Limoges enamels [13,26,53-62]. The Raman signature is sensitive both to composition and firing temperature of the pigment used [36-38,54-61]. Briefly, wavenumber of the $\mathrm{Pb}^{2+}$ strong peak decreases from $~ 140$ to $\sim 125 \mathrm{~cm}^{-1}$ when the temperature increases from $\sim 800^{\circ} \mathrm{C}$ to $1100^{\circ} \mathrm{C}$. The more common composition based on tin with or without the significant addition of antimony has first been identified in huafalang porcelains of the Kangxi period [27] and then in Qianlong (F1341C) painted porcelain. Multicomponent Sb-rich lead pyrochlore has also been observed in Kangxi huafalang porcelain (G5250, Table 7) [27] and then in this study, such as Qianlong F1467 cloisonné ewers and the F1440C painted enamelled bottle. It is important to note that the first use of European complex lead pyrochlore pigments appears to have been used especially for the green colour. However, achievement of green colours and a variety of green hues is a difficult task for glassmakers and potters before the apparition of chrome-based pigments such as Victoria green [2,98]. Nice spectra with a flat background are observed for green or yellow enamels of the F1467.1, R957 and F1440C artefacts and their specific signature is obvious. This complex composition had really started to be used in the middle of the 17th century in France for enamelled metal wares [24] and the use in the rare artefacts studied is also consistent with the use of pigments or at least recipes from Europe. One of the written evidences regarding the 17th century comes from the miniaturist Valerio Mariani in the treatise Della Miniatura published in 1620 [38]. In this manuscript, the recipe for Giallo de' Vasari (Potters' yellow) is mentioned, saying that the late Renaissance enamel consisted of a $\mathrm{Pb}-\mathrm{Sb}$ matrix with no significant amount of potassium. Thus, measuring the flux ratios $(\mathrm{Na} / \mathrm{K} / \mathrm{B}$ ?/Bi? ) in the enamels will be necessary. Two nice Raman spectra with strong peaks at 129 and $135 \mathrm{~cm}^{-1}$ were recorded for yellow and yellow-green areas of the oldest F1448C Kangxi tripod and the F1735C high vase with the Qianlong imperial mark, representing the proof of the use of a non-Chinese pigment for outstanding productions. 


\section{Conclusions}

This preliminary non-invasive analytical study confirms the capability of on-site Raman analysis with mobile set-up for characterization of very sophisticated enamelled wares produced during the 17th-18th centuries in China. The 17th century marks the period of close contact between Europe and China through the Jesuits hosted at the Chinese Court. The results particularly contribute to identification of the artefacts where ingredients or recipes from Europe for enamelling had been used, whatever the difficulties of the measurement conditions. In the exhibition places, performing Raman measurements is difficult since complete darkening of the environment is not possible and handling of the artefacts is limited. There is also no permission for cleaning the artefact, and time for access to the artefacts is also very limited. Furthermore, this study allows identification of the artefacts which require a more comprehensive study in the future by moving some of them to the laboratory or Synchrotron facilities if we succeed to have support to pay the packing cost and insurance.

On-site Raman microspectrometry appears to be an efficient technique to identify the characteristic phases as the signatures of European technology, by analysing rare and precious items such as those prepared at the Imperial Palace workshop. Artefacts hence identified should then be first analyzed by portable XRF to define precisely, for instance the $\mathrm{Sn} / \mathrm{Sb} / \mathrm{Zn} / \mathrm{Fe}$ ratio in green and yellow enamelled areas and $\mathrm{Co} / \mathrm{Mn} / \mathrm{Fe} / \mathrm{Ni} / \mathrm{As}$ in blue ones. Important information on the flux composition of the enamels is also missing: measuring the flux ratios $(\mathrm{Na} / \mathrm{K} / \mathrm{B}$ ?/Bi?) is also required. Preparing polished sections of the artefacts is the only method to get access to the stratigraphy of different glaze and enamel layers and allow the spot analysis of individual grains. In fact, shards of artefacts produced under the Qianlong reign or the end of Ming Dynasty are available (see e.g., [28,36-38,43,44,76]), on the contrary shards produced during the time of technology transfer, namely the end of the Kangxi reign and the short Yongzheng reigns are very rare [27]. A view of the microstructure on these sections is required to understand all the enamelling procedure. For instance, it was recently pointed out [99] that lead-based enamels of the Kangxi reign painted enamelled falang porcelains prepared at the Imperial Palace workshop were deposited directly on the body, not on the glazed body. This can be interpreted as proof of the link with the enamelling procedure of majolica as already recognized in the study of the first enamelled porcelain produced at Arita (Japan) during the first half of the 17th century under the guidance of Portuguese missionaries [36-38].

Collecting information on the relationship between Jesuits hosted in Japan and those present at the Kangxi Court could also provide complementary data. More information on the links between different types of craftsmen (potter, glassmaker, enameller) is also needed. In France, it is known that links between enamellers on watches (Blois and Paris workshops), those from Limoges workshops and glass workshops (Perrot, Orléans) were active during the 17th century and early 18th century. We also need more information between the links between these workshops. The craftsmen who contributed to the founding and activity of Imperial Palace workshops are Father J.F. Gerbillon (1654-1707, Chinese name Zhang Chen) and J. Bouvet (1656-1730, Bai Jin) who developed a chemistry workshop, while J.B. Gravereau (1690-1762, Chen Zhongxing), F.J. Castiglione (1688-1766, Italian, Lang Shining) and P.M. Grimaldi (1618-1686, Italian, Min Mingwo). These people were also requested to work on painted enamel décors. Information about the prior activity of these Jesuits is required to document their links and skills regarding the different steps involved in the production of painted enamelled artefacts, ingredients selection and preparation, painting in green state, firing, design of kiln, etc.

Author Contributions: Conceptualization, P.C. and B.Z.; methodology, P.C.; validation, P.C. and B.K.; investigation, P.C.; resources, B.Z., J.-B.C., Y.Y., and V.D.; writing — original draft preparation, P.C.; writing—review and editing, P.C., B.K., B.Z., J.-B.C, Y.Y., and V.D.; funding acquisition, Y.Y. All authors have read and agreed to the published version of the manuscript.

Funding: Please add: This research received no external funding.

Acknowledgments: Rong Wang, Curator at Palace Museum is acknowledged for her help in the dating/assignment of artefacts. Yong Lei and Huawen Liu from the Palace Museum and Professor Ludovic Bellot-Gurlet from MONARIS are kindly acknowledged for many discussions. This work has been made in the framework of the LIA 
CNRS-Palace Museum and Campus France PHC Cai Yuanpei programs in preparation of NAR EnamelFC. Michele Gironda (Elio, Bruker) is also acknowledged for pXRF measurements and data processing. Sarah Paronetto, Keeper at Fontainebleau castle and Catherine Gougeon from the Louvre Museum are acknowledged for their help for the access to the artefacts.

Conflicts of Interest: The authors declare no conflict of interest.

\section{References}

1. Colomban, P. Glazes and Enamels. In Encyclopedia of Glass Science, Technology, History, and Culture; Richet, P., Ed.; J. Wiley \& Sons Inc.: New York, NY, USA, 2020; Chapter 10.6.

2. Colomban, P.; Sagon, G.; Faurel, X. Differentiation of antique ceramics from the Raman spectra of their coloured glazes and paintings. J. Raman Spectrosc. 2001, 32, 351-360. [CrossRef]

3. Gauthier, M.-M. Émaux. In Encyclopédie Universalis; Encyclopédie Universalis: Paris, France, 1985; Volume 6, pp. 939-960.

4. Cooper, E. Ten Thousand Years of Pottery, 4th ed.; University of Pennsylvania Press: Philadelphia, PA, USA, 2000.

5. Moorey, P.R.S. Ancient Mesopotamian Materials and Industries, The Archaeological Evidence; Clarendon Press: Oxford, UK, 1994.

6. Roehrig, C.H. Glass. In Hatshepsut: From Queen to Pharaoh; Roehrig, C.H., Dreyfus, R., Keller, C.A., Eds.; The Metropolitan Museum of Art: New York, NY, USA, 2005; pp. 67-69.

7. Pierides, A. Jewellery in the Cyprus Museum; Republic of Cyprus the Department of Antiquities: Cyprus, Cyprus, 1971.

8. Ward, G.W.R. Enamel. In The Grove Encyclopedia of Materials and Techniques in Art; Oxford University Press: Oxford, UK, 2008; pp. 187-190.

9. Campbell, M. An Introduction to Medieval Enamels; HMSO: London, UK, 1983.

10. Kruta, V. The first Celtic expansion: Prehistory to history. In The Celts; Moscati, S., Ed.; Bompiani: Milano, Italy, 1991; pp. 195-210.

11. Buckton, D. Byzantine Enamel. In Byzantium: Treasures of Byzantine Art and Culture; Buckton, D., Ed.; The British Museum Press: London, UK, 1994; p. 18.

12. Kırmızı, B.; Colomban, P.; Quette, B. On-site analysis of Chinese Cloisonné enamels from fifteenth to nineteenth centuries. J. Raman Spectrosc. 2010, 41, 780-790.

13. Colomban, P.; Arberet, L.; Kırmız1, B. On-site Raman analysis of 17th and 18th century Limoges enamels: Implications on the European cobalt sources and the technological relationship between Limoges and Chinese enamels. Ceram. Int. 2017, 43, 10158-10165. [CrossRef]

14. Quette, B. (Ed.) Cloisonné: Chinese Enamels from the Yuan, Ming and Qing Dynasties; Bard Catalogue, Yale University Press: Yale, CT, USA, 2011.

15. Garner, S.H.M. Chinese and Japanese Cloisonné Enamels; Faber \& Faber: London, UK, 1962.

16. Zhou, L.L. Discussion on falangcai Enamels-And the Difference between falangcai and yangcai. Shanghai Bowuguan Jikan 2000, 8, 210-226.

17. Shih, C.F. Evidence of East-West exchange in the eighteenth century: The establishment of painted enamel art at the Qing Court in the reign of Emperor Kangxi. Natl. Palace Mus. Res. Q. 2007, 24, 45-94.

18. Zhou, S.Z. Research on Painted Enamels Porcelain Ware from the Qing Court; Wenwu Chubanshe: Beijing, China, 2008.

19. Lili, F. La Céramique Chinoise; China Intercontinental Press: Beijing, China, 2011.

20. Shih, C.F. Radiant Luminance: The Painted Enamelware of the Qing Imperial Court; The National Palace Museum of Taipei: Taipei, Taiwan, 2012.

21. Xu, X.D. Europe-China-Europe: The Transmission of the Craft of Painted Enamel in the Seventeenth and Eighteenth Centuries. In Goods from the East, 1600-1800 Trading Eurasia; Berg, M., Gottmann, F., Hodacs, H., Nierstrasz, C., Eds.; Palgrave Macmillan: London, UK, 2015; pp. 92-106.

22. Zhao, B.; Wang, G.Y.; Biron, I.; Colomban, P.; Hilaire-Pérez, L. La circulation des techniques de l'émail entre la France et la Chine du XVIIème au XIXème siècle. Le CNRS en Chine Bull. 2016, 21, 20-25. Available online: http://www.cnrs.fr/derci/IMG/pdf/cnrsenchine_21_fr_final_pour_le_site_cnrs.pdf (accessed on 15 December 2019). 
23. Curtis, E.B. A plan to the Emperor's glassworks. Arts Asiatiques 2001, 56, 81-90. [CrossRef]

24. Colomban, P.; Kirmız1, B.; Gougeon, C.; Gironda, M.; Cardinal, C. Pigments and glassy matrix of the 17th-18th century enamelled French watches: A non-invasive on-site Raman and pXRF study. J. Cult. Herit. 2020. [CrossRef]

25. Blanc, M.; Biron, I.; Colomban, P.; Notin, V. Emaux Peints de Limoges, XVe-XVIIIe siècles_La Collection du Musée des Arts Décoratifs; Les Arts Décoratifs: Paris, France, 2011.

26. Kırmızı, B.; Colomban, P.; Blanc, M. On-site analysis of Limoges enamels from sixteenth to nineteenth centuries: An attempt to differentiate between genuine artefacts and copies. J. Raman Spectrosc. 2010, 41, 1240-1247. [CrossRef]

27. Colomban, P.; Zhang, Y.; Zhao, B. Non-invasive Raman analyses of huafalang and related porcelain wares. Searching for evidence for innovative pigment technologies. Ceram. Int. 2017, 43, 12079-12088. [CrossRef]

28. Colomban, P.; Ambrosi, F.; Ngo, A.-T.; Lu, T.-A.; Feng, X.-L.; Chen, S.; Choi, C.-L. Comparative analysis of wucai Chinese porcelains using mobile and fixed Raman microspectrometers. Ceram. Int. 2017, 43, 14244-14256. [CrossRef]

29. Colomban, P.; Kırmızı, B. Non-invasive on-site Raman study of polychrome and white enamelled glass artefacts in imitation of porcelain assigned to Bernard Perrot and his followers. J. Raman Spectrosc. 2020, 51, 133-146. [CrossRef]

30. Colomban, P.; Lu, T.-A.; Milande, V. Non-invasive on-site Raman study of blue-decorated early soft-paste porcelain: The use of arsenic-rich (European) cobalt ores-Comparison with huafalang Chinese porcelains. Ceram. Int. 2018, 44, 9018-9026. [CrossRef]

31. Caggiani, M.-C.; Colomban, P. Testing of Raman spectroscopy as a non-invasive tool for the investigation of glass-protected pastels. J. Raman Spectrosc. 2011, 42, 790-798. [CrossRef]

32. Mancini, D.; Tournié, A.; Caggiani, M.-C.; Colomban, P. Testing of Raman spectroscopy as a non-invasive tool for the investigation of glass-protected miniature portraits. J. Raman Spectrosc. 2012, 43, 294-302. [CrossRef]

33. Henderson, J.; Tregear, M.; Wood, N. The technology of sixteenth- and seventeenth century Chinese cloisonné enamels. Archaeometry 1989, 31, 133-146. [CrossRef]

34. Su, Y.; Qu, L.; Duan, H.; Tarcea, N.; Shen, A.; Popp, J.; Hu, J. Elemental analysis-aided Raman spectroscopic studies on Chinese cloisonné wares and Painted enamels from the Imperial Palace. Spectrochim. Acta Part A Mol. Biomol. Spectrosc. 2015, 153, 165-170. [CrossRef]

35. Colomban, P.; Kirmızı, B.; Zhao, B.; Clais, J.-B. Investigation of the pigments and glassy matrix of the 18th century painted enamelled Chinese porcelains by non-invasive on-site Raman microspectometry. 2020. Unpublished work.

36. Montanari, R.; Alberghina, M.F.; Casanova Municchia, A.; Massa, E.; Pelagotti, A.; Pelosi, C.; Schiavone, S.; Sodo, A. A polychrome Mukozuke (1624-1644) porcelain offers a new hypothesis on the introduction of European enameling technology in Japan. J. Cult. Herit. 2017, 32, 232-237. [CrossRef]

37. Montanari, R.; Murakami, N.; Alberghina, M.F.; Pelosi, C.; Schiavone, S. The Origin of overglaze-blue enameling in Japan: New discoveries and a reassessment. J. Cult. Herit. 2019, 37, 94-102. [CrossRef]

38. Montanari, R.; Murakami, N.; Colomban, P.; Alberghina, M.F.; Pelosi, C.; Schiavone, S. European Ceramic technology in the Far East: Enamels and pigments in Japanese art from the 16th to the 20th century and their reverse influence on China. Herit. Sci. 2020. Submitted.

39. Wood, N. Chinese Glazes: Their Origins, Chemistry and Recreation; A \& C Black: London, UK, 1999; pp. $194-195$.

40. Gan, F. Origin and Evolution of Ancient Chinese Glass. In Ancient Glass Research Along the Silk Road; Gan, F., Brill, R., Shouyun, T., Eds.; World Scientific Publishing Co: Singapore, 2009.

41. Cui, J.; Wu, X.; Huang, B. Chemical and lead isotope analysis of some lead-barium glass wares from the Warring States Period, unearthed from Chu tombs in Changde City, Hunan Province, China. J. Archaeol. Sci. 2011, 38, 1671-1679. [CrossRef]

42. Kingery, W.D.; Vandiver, P.B. The Eighteenth-Century Change in Technology and Style from the Famille-Verte Palette to the Famille-Rose Palette. In Technology and Style; Kingery, W.D., Ed.; Ceramics and Civilization Series; The American Ceramic Society: Colombus, OH, USA, 1986; Volume 2, pp. 363-381.

43. Van Pevenage, J.; Lauwers, D.; Herremans, D.; Verhaeven, E.; Vekemans, B.; De Clercq, W.; Vincze, L.; Moens, L.; Vandenabeele, P. A Combined Spectroscopic Study on Chinese Porcelain Containing Ruan-Cai Colours. Anal. Methods 2014, 6, 387-394. [CrossRef] 
44. Giannini, R.; Freestone, I.C.; Shortland, A.J. European cobalt sources identified in the production of Chinese famille rose porcelain. J. Archaeol. Sci. 2017, 80, 27-36. [CrossRef]

45. Ramsey, J.D.; McCreery, R.L. In situ Raman microscopy of chromate effects on corrosion pits in aluminum alloy. J. Electrochem. Soc. 1999, 146, 4076-4081. [CrossRef]

46. Frost, R.L. Raman Microscopy of Selected Chromate Minerals. J. Raman Spectrosc. 2004, 35, $153-158$. [CrossRef]

47. Colomban, P.; Milande, V.; Le Bihan, L. On-site Raman Analysis of Iznik pottery glazes and pigments. J. Raman Spectrosc. 2004, 35, 527-535. [CrossRef]

48. Froment, F.; Tournié, A.; Colomban, P. Raman identification of natural red to yellow pigments: Ochre and iron-containing ores. J. Raman Spectrosc. 2008, 39, 560-568. [CrossRef]

49. Koleini, F.; Colomban, P.; Pikirayi, I.; Prinsloo, L.C. Glass beads, markers of ancient trade in sub-Saharan Africa: Methodology, State of the Art and Perspectives. Heritage 2019, 2, 144. [CrossRef]

50. Ricciardi, P.; Colomban, P.; Tournié, A.; Macchiarola, M.; Ayed, N. A non-invasive study of Roman Age mosaic glass tesserae by means of Raman spectroscopy. J. Archaelog. Sci. 2009, 36, 2551-2559. [CrossRef]

51. Neri, E.; Morvan, C.; Colomban, P.; Guerra, M.F.; Prigent, V. Late Roman and Byzantine mosaic opaque "glass-ceramics" tesserae (5th-9th century). Ceram. Int. 2016, 42, 18859-18869. [CrossRef]

52. Kırmızı, B.; Göktürk, H.; Colomban, P. Colouring agents in the pottery glazes of western Anatolia: A new evidence for the use of Naples yellow pigment variations during the late Byzantine period. Archaeometry 2015, 57, 476-496. [CrossRef]

53. Sakellariou, K.; Miliani, C.; Morresi, A.; Ombelli, M. Spectroscopic investigation of yellow majolica glazes. J. Raman Spectrosc. 2004, 35, 61-67. [CrossRef]

54. Sandalinas, C.; Ruiz-Moreno, S. Lead-tin-antimony yellow-Historical manufacture, molecular characterization and identification in seventeenth-century Italian paintings. Stud. Conserv. 2004, 49, 41-52. [CrossRef]

55. Sandalinas, C.; Ruiz-Moreno, S.; Lopez-Gil, A.; Miralles, J. Experimental confirmation by Raman spectroscopy of a $\mathrm{Pb}-\mathrm{Sn}-\mathrm{Sb}$ triple oxide yellow pigment in sixteenth-century Italian pottery. J. Raman Spectrosc. 2006, 37, 1146-1153. [CrossRef]

56. Rosi, F.; Manuali, V.; Miliani, C.; Brunetti, B.G.; Sgamellotti, A.; Grygar, T.; Hradil, D. Raman scattering features of lead pyroantimonate compounds. Part I: XRD and Raman characterization of $\mathrm{Pb}_{2} \mathrm{Sb}_{2} \mathrm{O}_{7}$ doped with tin and zinc. J. Raman Spectrosc. 2009, 40, 107-111. [CrossRef]

57. Ricciardi, P.; Colomban, P.; Tournié, A.; Milande, V. Non-destructive on-site identification of ancient glasses: Genuine artefacts, embellished pieces or forgeries? J. Raman Spectrosc. 2009, 40, 604-617. [CrossRef]

58. Pereira, M.; de Lacerda-Aroso, T.; Gomes, M.J.M.; Mata, A.; Alves, L.C.; Colomban, P. Ancient Portuguese ceramic wall tiles («Azulejos»): Characterization of the glaze and ceramic pigments. J. Nano Res. 2009, 8, 79-88. [CrossRef]

59. Pelosi, C.; Agresti, G.; Santamaria, U.; Mattei, E. Artificial yellow pigments: Production and characterization through spectroscopic methods of analysis. e-Preserv. Sci. 2010, 7, 108-115.

60. Rosi, F.; Manuali, V.; Grygar, T.; Bezdicka, P.; Brunetti, B.G.; Sgamellotti, A.; Burgio, L.; Seccaroni, C.; Miliani, C. Raman scattering features of lead pyroantimonate compounds: Implication for the non-invasive identification of yellow pigments on ancient ceramics. Part II. In situ characterisation of Renaissance plates by portable micro-Raman and XRF studies. J. Raman Spectrosc. 2011, 42, 407-414.

61. Cartechini, L.; Rosi, F.; Miliani, C.; D’Acapito, F.; Brunetti, B.G.; Sgamellotti, A. Modified Naples yellow in Renaissance majolica: Study of $\mathrm{Pb}-\mathrm{Sb}-\mathrm{Zn}$ and $\mathrm{Pb}-\mathrm{Sb}$-Fe ternary pyroantimonates by X-ray absorption spectroscopy. J. Anal. At. Spectrom. 2011, 26, 2500-2507. [CrossRef]

62. Colomban, P.; Maggetti, M.; d'Albis, A. Non-invasive Raman identification of crystalline and glassy phases in a 1781 Sèvres Royal Factory soft paste porcelain plate. J. Eur. Ceram. Soc. 2018, 38, 5228-5233. [CrossRef]

63. Colomban, P.; Sagon, G.; Louhichi, A.; Binous, H.; Ayed, N. Identification par Microscopie Raman des Tessons et Pigments de Glaçures de Céramiques de l'Ifriqiya (Dougga: XIe-XVIIIe siècles). Revue d'Archéomètrie 2001, 25, 101-112. [CrossRef]

64. Jehlicka, J.; Vitek, P.; Edwards, H.G.M.; Hargreaves, M.D.; Capoun, T. Fast detection of sulphate minerals (gypsum, anglesite, baryte) by a portable Raman spectrometer. J. Raman Spectrosc. 2009, 40, 1082-1086. [CrossRef]

65. Colomban, P. Polymerization degree and Raman identification of ancient glasses used for jewellery, ceramic enamels and mosaics. J. Non-Crystall. Solids 2003, 323, 180-187. [CrossRef] 
66. Colomban, P.; Paulsen, O. Non-destructive Raman Determination of the Structure and Composition of Glazes by Raman Spectroscopy. J. Amer. Ceram. Soc. 2005, 88, 390-395. [CrossRef]

67. Colomban, P.; Tournié, A.; Bellot-Gurlet, L. Raman identification of glassy silicates used in ceramic, glass and jewellery: A tentative differentiation guide. J. Raman Spectrosc. 2006, 37, 841-852. [CrossRef]

68. Colomban, P. Non-Destructive Raman Analysis of Ancient Glasses and Glazes, in Modern Methods for Analysing Archaeological and Historical Glass, 1st ed.; Janssens, K., Ed.; John Wiley \& Sons Ltd: London, UK, 2012; pp. 275-300.

69. Labet, V.; Colomban, P. Vibrational properties of silicates: A cluster model able to reproduce the effect of " $\mathrm{SiO}_{4}$ " polymerization on Raman intensities. J. Non-Crystall. Solids 2013, 370, 10-17. [CrossRef]

70. Manoun, B.; Azdouz, M.; Azrour, M.; Essehli, R.; Benmokhtar, S.; El Ammari, L.; Ezzahi, A.; Ider, A.; Lazor, P. Synthesis, Rietveld refinements and Raman spectroscopic studies of tricationic lacunar apatites $\mathrm{Na}_{1-\mathrm{x}} \mathrm{K}_{\mathrm{x}} \mathrm{Pb}_{4}\left(\mathrm{AsO}_{4}\right)_{3}(0<\mathrm{x}<1)$. J. Mol. Struct. 2011, 986, 1-9.

71. Bernardini, S.; Bellatreccia, F.; Municchia, A.C.; Della Ventura, G.; Sodo, A. Raman spectra of natural manganese oxides. J. Raman Spectrosc. 2019, 50, 873-888. [CrossRef]

72. Geyssant, J. Secret du verre rouge transparent de Bernard Perrot et comparaison avec celui de Johann Kunckel. In Bernard Perrot (1640-1709), Secrets et Chefs-d'œuvre des Verreries Royales d'Orléans; Catalogue, Klinka Ballesteros, I., de Valence, C., Maitte, C., Ricke, H., Eds.; Musée des Beaux-Arts d'Orléans—SOMOGY Editions d'Arts: Paris, France, 2013; pp. 51-54.

73. Colomban, P. The Use of Metal Nanoparticles to Produce Yellow, Red and Iridescent Colour, from Bronze Age to Present Times in Lustre Pottery and Glass: Solid State Chemistry, Spectroscopy and Nanostructure. J. Nano Res. 2009, 8, 109-132. [CrossRef]

74. Hunt, L.B. The true story of Purple of Cassius. Gold Bull. 1976, 9, 134-139. [CrossRef]

75. Lewis, W. Glass and Enamel by Preparations of Gold, Commercium Philosophico Technicum or The Philosophical Commerce of Arts: Designed as an Attempt to Improve Arts, Trades, and Manufactures; London, UK, 1763; p. 170.

76. Jiang, X.; Ma, Y.; Chen, Y.; Li, Y.; Ma, Q.; Zhang, Z.; Wang, C.; Yang, Y. Raman analysis of cobalt blue pigment in blue and white porcelain: A reassessment. Spectrochim. Acta Part A Mol. Biomol. Spectrosc. 2018, 190, 61-67. [CrossRef] [PubMed]

77. Colomban, P.; Schreiber, H. Raman Signature Modification Induced by Copper Nanoparticles in Silicate Glass. J. Raman Spectrosc. 2005, 36, 884-890. [CrossRef]

78. Colomban, P.; Tournié, A.; Ricciardi, P. Raman spectroscopy of copper nanoparticle-containing glass matrices: The ancient red stained-glass windows. J. Raman Spectrosc. 2009, 40, 1949-1955. [CrossRef]

79. Sciau, P.; Noé, L.; Colomban, P. Metal nanoparticles in contemporary potters' master pieces: Lustre and red "pigeon blood" potteries: Models to understand the ancient technology. Ceram. Int. 2016, 42, 15349-15357. [CrossRef]

80. Brun, N.; Mazerolles, L.; Pernot, M. Microstructure of opaque red glass containing copper. J. Mater. Sci. Lett. 1991, 10, 1418-1420. [CrossRef]

81. Kingery, W.D.; Vandiver, P.B. Song Dynasty Jun (Chun) ware glazes. Am. Ceram. Bull. 1983, 62, 1269-1274.

82. Freestone, I.C.; Barber, D.J. The Development of the Colour of Sacrificial Red Glaze with Special Reference to a Qing Dynasty Saucer Dish. In Chinese Copper Red Wares; Scott, R.E., Ed.; Percival David Foundation of Chinese Art, Monograph Series N ${ }^{\circ} 3$; University of London, School of Oriental and African Art: London, UK, 1992; pp. 53-62.

83. Yang, Y.M.; Feng, M.; Ling, X.; Mao, Z.Q.; Wang, C.S.; Sun, X.M.; Guo, M. Microstructural analysis of the color-generating mechanism in Ru ware, modern copies and its differentiation with Jun ware. J. Archaeol. Sci. 2005, 32, 301-310. [CrossRef]

84. Li, Y.Q.; Yang, Y.M.; Zhu, J.; Zhang, X.G.; Jiang, S.; Zhang, Z.X.; Yao, Z.Q.; Solbrekken, G. Colour-generating mechanism of copper-red porcelain from Changsha Kiln (AD $7^{\text {th }}-10$ th century), China. Ceram. Int. 2016, 42, 8495-8500. [CrossRef]

85. Wayne Richardson, H.W. Handbook of Copper Compounds and Applications; CRC Press: Boca Raton, FL, USA, 1997; pp. 154-155.

86. Colomban, P.; Treppoz, F. Identification and Differentiation of Ancient and Modern European Porcelains by Raman Macro- and Microspectroscopy. J. Raman Spectrosc. 2001, 32, 93-102. [CrossRef] 
87. Colomban, P.; Robert, I.; Roche, C.; Sagon, G.; Milande, G. Identification des porcelaines «tendres » du $18^{\mathrm{e}}$ siècle par spectroscopie Raman: Saint-Cloud, Chantilly, Mennecy et Vincennes/Sèvres. Rev. d'Archéomtrie 2004, 28, 153-167. [CrossRef]

88. Magetti, M.; d'Albis, A. Phase and compositional analysis of a Sèvres sof paste porcelain plate from 1781, with a review of early porcelain techniques. Eur. J. Mineral. 2017, 29, 347-367. [CrossRef]

89. Colomban, P. Rocks as blue, green and black pigments/dyes of glazed pottery and enamelled glass artefacts -A review. Eur. J. Mineral. 2014, 25, 863-879. [CrossRef]

90. Kissin, S.A. Five element (Ni-Co-As-Ag-Bi) veins. Geosci. Can. 1992, 19, 113-124. Available online: https://journals.lib.unb.ca/index.php/gc/article/view/3768/4282/ (accessed on 15 December 2019).

91. Mancini, D.; Dupont-Logié, C.; Colomban, P. On-site identification of Sceaux porcelain and faience using a portable Raman instrument. Ceram. Int. 2016, 42, 14918-14927. [CrossRef]

92. Merrifield, M.P. Medieval and Renaissance Treatises on the Arts of Painting (1849); Reprint: New York NY, USA, 1967; p. 334.

93. Bertran, H.; Reboulleau; Magnier; Romain, A. Nouveau Manuel Complet de la Peinture sur Verre, sur Porcelaine et sur émail; Encyclopédie-Roret, L. Mulo: Paris, France, 1913.

94. Brill, R.H.; Cahill, N.D. A red opaque glass from Sardis and some thoughts on red opaques in general. J. Glass Stud. 1988, 30, 16-27.

95. Maltoni, S.; Silvestri, A. A Mosaic of Colors. Investigating Production Technologies of Roman Glass Tesserae From Northeastern Italy. Minerals 2018, 8, 255. [CrossRef]

96. Colomban, P.; March, G.; Mazerolles, L.; Karmous, T.; Ayed, N.; Ennabli, A.; Slim, H. Raman identification of materials used for jewellery and mosaics in Ifriqiya. J. Raman Spectrosc. 2003, 34, 205-213. [CrossRef]

97. Freestone, I.C.; Meek, N.; Sax, M.; Higgitt, C. The Lycurgus Cup-A Roman nanotechnology. Gold Bull. 2007, 40, 270-277. [CrossRef]

98. Epler, R.A.; Epler, D.R. Glazes and Glass Coatings; The American Ceramic Society: Westerville, OH, USA, 2000.

99. Shi, N.C. Analyse scientifique des couleurs falang d'objets conservés au Palais ou retrouvés en contexte archéologique. In Proceedings of the French-Chinese Meeting on Enamelling Technology, Paris, France, 10 September 2019.

(C) 2020 by the authors. Licensee MDPI, Basel, Switzerland. This article is an open access article distributed under the terms and conditions of the Creative Commons Attribution (CC BY) license (http://creativecommons.org/licenses/by/4.0/). 